\title{
Kentsel Dönüşümde Sosyal Etki Değerlendirmesi: Sümer Mahallesi Kentsel Dönüşüm Projesi
}

\author{
Tuba DEMIREL ${ }^{1 *}$, Neslihan SERDAROĞLU SAĞ ${ }^{1}$ \\ ${ }^{1}$ Konya Teknik Üniversitesi, Mimarlık ve Tasarım Fakültesi, Şehir ve Bölge Planlama Bölümü, 42030, KONYA
}

\section{Öz}

Kentsel dönüşümün, kentlerde ve toplumda oluşturduğu etkilerin incelenmesi ve belirlenen hedeflere ulaşılabilmesi için gerekli stratejilerin belirlenmesi, başarılı kentsel dönüşümlerin ön koşuludur. Kentsel dönüşüm projelerinde en önemli problemlerden birisi; sosyal etkilerin değerlendirilmesine yönelik çalışmaların yetersiz olması ve özellikle dönüşüm alanında yaşayan halkın beklentilerinin yönetilmesine yönelik stratejilerin, sosyal etki değerlendirmesi yapılmaksızın belirlenmesi ve başarıya ulaşamamasıdır. Bu nedenle makalede, kentsel dönüşümde sosyal etki değerlendirmesine yönelik deneysel bir çalısma gerçekleştirmek amaçlanmıştır. Makale literatür araştırması ve alan çalışması olmak üzere iki aşamada, nicel ve nitel değerlendirmeleri içeren karma bir metodoloji ile kurgulanmıştır. Kentsel dönüşüm ve sosyal etki değerlendirmesine yönelik literatür çalışmasının akabinde, İstanbul kenti Zeytinburnu ilçesi Sümer Mahallesi Kentsel Dönüşüm Projesi örnekleminde alan çalışması yapılmıştır. Sosyal etki değerlendirmesi için Bina Sokak Mahalle Yöntemi ile oluşturulan kartlar kullanılarak, dönüşüm alanında yaşayan kişilerle derinlemesine görüşmeler gerçekleştirilmiştir. Sonuç olarak; görüşülen kişilerin mahalle ile ilgili değerlendirmelerinde mahalle kültürünün, mevcut çarşının ve küçük esnafların varlığını sürdürmesi, sosyal aktivite ve ortak kullanım alanlarının geliştirilmesi ve yerel iş olanaklarının artırılması konularına vurgu yaptıkları belirlenmiştir. Sokak ile ilgili değerlendirmelerinde ise, sokak kültürünün, komşuluk ilişkilerinin ve güven duygusunun devam etmesi, farklı gelir düzeyine ve yaşam alışkanlıklarına hitap eden konutların oluşturulması, çocuk oyun alanlarının ve engellilere yönelik tasarımların geliştirilmesi, canlı, hareketli, yaşayan sokakların oluşturulması konularına dikkat çekmişlerdir. Derinlemesine görüşmelerde kişilerin projeyi sahiplenmesi noktasında fikirlerinin önemsenmesine işaret etmeleri, özellikle sosyal etki değerlendirmesinin önemini vurgulamıştır.

Anahtar Kelimeler: Kentsel dönüşüm, sosyal etki değerlendirmesi, bina sokak mahalle yöntemi, Zeytinburnu, Sümer Mahallesi.

\section{Social Impact Assessment in Urban Regeneration: Sümer Neighbourhood Urban Regeneration Project}

\begin{abstract}
An urban regeneration project can only be succesful after fullfilling the following preconditions. First of all there is a need for research on the effects of the project in the cities and also the consequences for the society living there. Therefore the necessary strategies must be determined and examined. One of the most important problems that leads to failure of a urban regeneration project is the fact that there is insufficient research considering the social effects assessment in general situations but in most of the cases the expectations of the citizens living in the regeneration area are not rapported to obtain a comform working strategy. Therefore in this articele there is aimed to perform an experimental study on the social effect assessment in cases of urban regeneration projects. This article is a result of at one side literature study and at the other hand field research that is based on a mixed methodoloy that has taken quantitave and also qualitative research in consideration. After realizing the literature study concerning urban regeneration and social effect assessment the research is tested with a field study in Istanbul City. A few samples of the urban regeneration project in the District Zeytinburnu and more specific in the Neighboorhoud Sümer formed were taken in consideration during the resaerch. The social effects assessment is based on cards created with the building, street and neighbourhood strategy. The regeneration project is
\end{abstract}




\begin{tabular}{llll}
\hline Research Article & Bartın Orman Fakultesi Dergisi, & Journal of Bartin Faculty of Forestry \\
Araştırma Makalesi & 21(2): 350-368, & p-ISSN :1302-0943 \\
DOI: 10.24011/ barofd.569896 & 15 Ağustos/August, 2019 & e-ISSN :1308-5875
\end{tabular}

realized without in-depth interviews with the citizens of the regeneration area. The final conclusion after field research in the neighboorhood shows that interviewees emphasazed on the following issues: they want that the existing street culture, the existing arcade and local small shops must be maintained and also after the regeneration they want that there will be more attention for social and common use areas and the increasing of local employment opportunities. Related to their evaluations concerning the street they draw attention to the following topics: they want that the existing street culcure, relationships between neighboors and the feeling of trust must be maintained, the new residences must be created in accordance to the differences in the levels of income and comform the different lifestyles, the improuvement of playgrounds and more opportunities for disabled people and a street with a feeling of real life are very important. According to the results of the in-depth interviews can be concluded that during the process of regeneration there priorities and suggestions were not taken in the execution of the project. Their feelings emphasize the importance of social effect assessment of urban regeneration.

Keywords: Urban regeneration, social impact assessment, building, street and neighboorhood method, Zeytinburnu, Sümer Neighbourhood. 


\section{Giriş}

Kentler; kültürel, sosyal ve fiziksel etkileşimlerin sonucu ortaya çıkmış toplumun ve bireylerin bir arada bulundukları sosyalleştikleri mekânlardır. Kentlerde etkileşimler ve toplumdaki karşılıklı ilişkiler sürekliliği olan bir değişim süreci yaşanmasına neden olmaktadır. Bu değişim sonucu tarihi süreçte farklı biçimleriyle ortaya çıkan kentsel dönüşüm kavramı, günümüzün en çok tartışılan konularından birisi olarak güncelliğini sürdürmektedir.

Yapılan kaynak araştırmasına yönelik, kentsel dönüşümün kavramsal altyapısı (Akkar, 2006; Ataöv ve Osmay, 2007; Özden, 2008; Serdaroğlu Sağ, 2011), fiziksel-tasarım boyutu (Yenice, 2011; Yağc1, 2014; Usalan, 2017; Bektaş, 2014); ve ekonomik boyutu (Öngören ve diğ., 2015; İMSAD, 2014), hukuki boyutu (Demirel, 2018; Seyidoğulları, 2016; Öngören ve Çolak, 2013) ve sosyal boyutuna (Dinçel, 2016; Ertaş,2011; Saraç, 2014) ilişkin kentsel dönüşümün boyutları çerçevesindeki çalışmalar incelenmiştir. Türkiye’de kentsel dönüşüm süreçlerinde genel olarak çevresel, fiziksel tasarım ve ekonomik etkileri göz önüne bulunduran çalışmaların ağırlık kazandığı görülmüştür. Kentsel dönüşüm projelerinin etkin bir şekilde problemlerle başa çıkabilmesi ve olumlu sonuçlarının artırabilmesi için sosyal, ekonomik, fiziksel (yapılı çevre) ve çevresel boyutlar arasındaki dengeyi gözeten sürdürülebilirlik ilkeleri çerçevesinde değerlendirilmelidir (Akkar, 2006; McCarty, 2007; Chan ve Lee, 2008; Turcu, 2010). Adı geçen her boyutun özel olarak araştırılması ve etkilerinin belirlenmesi, bu etkilerin yönlendirilmesine yönelik kararların üretilmesi gereklidir. Mekânları yeni güçlü yapılar oluşturarak dönüştürmek bireylere daha sağlıklı daha kaliteli yaşam ortamları sunmak anlamında olumlu katkılarda bulunabilir ancak gelenek, göreneklerine bağlı olarak, bir sokak kültürü, komşuluk ilişkileri, yardımlaşma ve dayanışma hali içinde olan Türk toplumu için yeterli olmamaktadır. Dönüşümle toplumun isteklerinden, beklentilerinden uzaklaştırılması, yakın ilişki içinde yaşadıkları komşuların değişmesi, alıştıkları yardımlaşma, sohbet ilişkilerinin ortadan kaldırılması, toplumsal yalnızlaşmaya sebebiyet verebilecektir (Ertaş, 2001).

Kentsel dönüşüm projelerinde en önemli problemlerden birisi; sosyal etkilerin değerlendirilmesine yönelik çalışmaların yetersiz olması ve özellikle dönüşüm alanında yaşayan halkın beklentilerinin yönetilmesine yönelik stratejilerin, sosyal etki değerlendirmesi yapılmaksızın belirlenmesi ve başarıya ulaşamamasıdır. Sosyal boyutu ve sosyal etki değerlendirmesi yetersiz olan kentsel dönüşüm projeler, yaşayan halk üzerinde; geleneklerin yaşatılamaması, gelecek endişesi, ihtiyaçlarına yönelik hizmetlerin eksik kalması, kendini mekâna ait hissetmeme ve yalnızlık gibi olumsuz etkiler oluşturmaktadır. Makalede, kentsel dönüşüm sonucunda halk üzerinde oluşabilecek olumsuz etkilerin sosyal etki değerlendirmesi ile ortadan kaldırılabileceği düşüncesinden hareketle, kentsel dönüşümde sosyal etki değerlendirmesinin önemini vurgulamak amaçlanmıştır.

$\mathrm{Bu}$ çalışma kentsel dönüşümü ve sosyal etki değerlendirmesi ile yaşayanlar üzerinde oluşturabileceği etkiler çerçevesinde değerlendirilerek planlama kararlarını yönlendirici sonuçlar oluşturması bakımından önem taşımaktadır. Böylece, kentsel dönüşümün yaşayanlar üzerinde oluşturacağı etkiler olumlu, proje de başarılı bir proje olabilecektir. Bu çerçevede bu çalışmada kentsel dönüşüm sonucunda yaşayanlar üzerinde oluşabilecek olumsuz etkilerin, proje öncesinde ve/veya sürecinde sosyal etki değerlendirmesi ile ortadan kaldırılabileceği düşüncesinden hareketle öneriler geliştirilmesi amaçlanmıştır.

\subsection{Kentsel Dönüşüm ve Sosyal Etki Değerlendirmesi}

Roberts (2000), kentsel dönüşümü, kapsamlı ve bütünleşik (entegre) bir vizyon ve eylem olarak, bir alanın ekonomik, fiziksel, toplumsal ve çevresel koşullarının sürekli iyileştirilmesini sağlamaya çalışmak olarak tanımlamaktadır. Dolayısıyla, kentsel dönüşüm, çöküntüye uğramış kentsel mekânın ekonomik, toplumsal, fiziksel ve çevresel koşullarını kapsamlı ve bütünleşik olarak iyileştirmek için uygulanan strateji ve eylemlerin bütünüdür. Bu nedenle, kentsel dönüşüm, yeni kentsel alanların planlanmasından ziyade, mevcut yerleşilmiş kentsel alanların planlanması ve yönetimi ile ilgilidir (Keleş, 2006).

Uygulanmış dönüşüm projelerinin kentsel ölçekte olumsuz etkilerinin görülmesinin ardından kentsel dönüşümün yalnızca bir fiziksel planlama çalışması gibi ele alınamayacağı bir gerçek olarak karşımıza çıkmaktadır. Çünkü kentsel dönüşüm çok aktörlü bir süreçtir ve bu sürecin fiziksel/tasarım, sosyal, ekonomik ve yasal/yönetsel açlardan paydaşların beklentilerini karşılayacak bütüncül ve dengeli bir yapıda olması gerekmektedir (Rodney ve Clark, 2000). Türkiye'de uygulanan birçok dönüşüm uygulaması genelde fiziksel mekânın dönüşümü kapsamında ele alınmakta; toplumsal, ekonomik ve yasal boyutları göz ardı edilmektedir. Fiziksel dönüşümün kar güdüsü ile ön planda tutulduğu projeler, toplumsal eşitsizliğin görüldüğü ve doğal, tarihi ve kültürel çevrenin verimsiz kullanıldığı kentsel mekânlar yaratmış, ayrıca ekonomik şartların iyileştirilmesine yönelik bir başarı sağlayamamıştır (Gittell, 1992). Bu durum kentsel dönüşümün özellikle sosyal boyutunu ve etkilerinin önemini vurgulamayı gerektirmektedir. 
Sosyal etki, insan yaşamı ve çevresine yapılan müdahalelerden kaynaklanan değişim olarak tanımlanmaktadır. $\mathrm{Bu}$ değişimler insanların günlük yaşamını, ekonomik hayatını, yaşam tarzını, birbirileri ve toplum geneli ile olan ilişkilerini ve değerler, inançlar ve kurallar gibi kültürel etkileri kapsamaktadır (Göksu ve ark. 2015). Sosyal etki kavramının ortaya çıkışı çevresel etki değerlendirmeleri sonrasında gündeme gelmiştir. Projelerin çevresel etkilerin değerlendirmesi, ilk olarak 1970 yılında Amerika'da Ulusal Çevre Politikası Kanunu (NEPA) kapsamında ortaya çıkmıştır. NEPA'nın uygulanmasının ardından Avustralya, Kanada, Filipinler gibi ülkelerde de etki değerlendirmesini mecbur tutan çevre kanunları uygulamaya girmiştir. Bu dönemde sosyal etki değerlendirmeleri, Çevresel Etki Değerlendirmesinin (ÇED) bir alt başlı̆̆ olarak yer bulmuştur (Burdge ve Taylor, 2012). "Sosyal Etki Değerlendirme" terimi ilk olarak 1973 yılında, Trans-Alaska Boru Hattı için hazırlanmış çevresel etki beyannamesinde kullanılmıştır. 1950'lerde ve 1960'larda kitle turizminin yoğun bir şekilde deneyimlenmeye başlandığı için sosyal etkiyi anlamaya yönelen antropolojik çalışmalar yapılmış, 1970'lerde ise sosyal bilimciler maden ocağı bulunan yerleşim merkezlerinde yaptıkları etki ve tasarım çözümlerine yönelik araştırmalar, sosyal etki değerlendirmesinin bir kavram olarak ele alındığı ilk dönemlerdir (Vanclay, 2012). 1980'lerle birlikte proje, planlamada sosyal ve ekonomik bakış açısı geliştirilmesinin önemi ile de paralel olarak, SED'in önemi artmaya başlamıștır. Dünya Bankası gibi uluslararası organizasyonlar da projelerin sosyal yönlerinin değerlendirilmesine yönelik tavsiye niteliğinde çalışmalar üretmeye başlatmıştır (Burdge ve Taylor, 2012). 1990'lardan itibaren ekonomi ve ticaret, eğitim ve istihdam, suç ve yoksunluk, sosyal donatı alanları, sosyal dışlanma, kişilerin refah ve sağlı̆̆ gibi konularla etki değerlendirmesinin kapsamı genişlemiştir. Günümüzde Avustralya'da şirketler faaliyetlerini uygulamaya koymadan önce, Hindistan'da yer değiştirme planları uygulamaya geçmeden önce SED raporu hazırlamaktadır. AB'de ise sadece ÇED bir zorunluluktur ancak, değerlendirmelerde kamu sağlığı faktörünün önemi vurgulanmaktadır (Burdge ve Taylor, 2012).

Sosyal Etki Değerlendirmesi (SED); etkileyen ve etkilenenler arasında etkileşim sürecinde oluşan yaşam ve mekâna ilişkin etkilerin, muhtemel olumsuz sonuçlarının minimize edilmesine yönelik kapsamlı ve katılımcı yönetim sürecidir. Etkileyen ve etkilenen arasındaki etkileşim sürecinin sosyal ve mekânsal değişime duyarlı hale getirilmesi amacıyla oluşturulan SED raporları, karar alıcıları yönlendirmeyi amaçlamaktadır (Göksu ve ark. 2015). "SED, sosyal değişimin gerçekleştiği bölgelerde, bir plan, proje, program ya da politikanın yaratacağı değişimin olumlu ve olumsuz etkilerini anlamaya ve olumsuz etkilerini azaltmaya yönelik yapılan analiz, izleme ve planlama çalışmalarını içerir. SED çalışmaları, sosyal ve bireysel gereksinmelere yanıt veren, eşitlikçi ve erişilebilir mekânlar oluşturmaya katkı sağlamayı hedefler. SED bu anlamda, yaşamı merkezine alan bir yaklaşım ve yöntem geliştirmeyi hedefleyen, uygulamaya dönük bir etki yönetim aracı olarak da tanımlanabilir" (Göksu ve ark. 2015).

Sosyal Etki Değerlendirmesi, planlı müdahalelerin (politikalar, programlar, planlar, projeler) ve bu müdahalelere bağlı olarak meydan gelen sosyal değişimden doğrudan veya dolaylı olarak kaynaklanan her türlü pozitif veya negatif etkinin değerlendirilmesi, izlenmesi ve yönetimidir (International Association for Impact Assessment (IAIA), 2009). Burada temel amaç sürdürülebilir ve eşitlikçi biyofiziksel ve sosyal bir çevrenin oluşturulmasıdır (Karakitapoğlu ve diğ., 2013). Sosyal Etki Değerlendirmesi, kalkınmanın faydalarını en üst seviyeye çıkarmayı ve oluşacak maliyetleri de en aza indirmeyi amaçlar. SED, oluşacak etkileri daha önceden belirler ve hangi müdahalenin sürdürülmesi ve nasıl gelişim göstereceği konusunda daha iyi kararlar almayı amaçlar. Ayrıca belirli bir planlı müdahalede veya ilgili herhangi faaliyetten gelen zararı minimuma indirmeyi ve faydaları ise en üst seviyeye çıkarmak için azaltma tedbirleri uygular (IAIA, 2009). Etki değerlendirmesinin amacı; daha ekolojik, daha sosyo- kültürel ve daha ekonomik olarak sürdürülebilir ve eşitlikçi bir çevrenin meydana getirilmesini sağlamaktır (Vanclay, 2003). SED çalışmalarının en önemli amaçlarından bir tanesi de tüm paydaşların farkındalığını arttırmak, sürecin bir parçası olduklarına ve süreçte söz sahibi olduklarına dair bilinci yükseltmektir. Bugüne kadar ülkemizde ve dünyadaki deneyimler katılımcı anlayışın çok daha olumlu bir sonuç verdiğini göstermiştir (Gürtuna, 2016).

Türkiye'de Kentsel Dönüşüme yönelik SED kapsamında şu an uygulanmış olan bir örnek bulunmadığ1 tespit edilmiştir. Ancak, Ali Faruk Göksu'nun (Göksu ve ark. 2015) “On Proje Onlarca Etki Programı” çalışması ile Dünya Bankası'nın ‘Sürdürülebilir Şehirler Programı Kentsel Tasarım Çalıştayı Yöntemi’ kapsamında Çevre ve Şehircilik Bakanlığı, Gaziantep Büyükşehir Belediyesi ve Şahinbey Belediyesi işbirliği ile yürütülen ve Kentsel Strateji şirketi tarafından hazırlanan Gaziantep ili Şahinbey ilçesi riskli alanına ilişkin 'Sosyal Etkiye Duyarlı Tasarım Süreci (Kentsel Strateji, 2014)' çalışmaları sosyal etki değerlendirmesini yönlendiren öncü çalışmalardır. Bu çalışmalarda dönüşüm ile alanda yaşayan kişiler üzerinde oluşan/oluşacak etkiler araştırma ve gözlemlerle tespit edilmiştir.

Bu kapsamda, örnek çalışmalardan hareketle, İstanbul'un en kapsamlı kentsel dönüşüm projelerinden biri olan Zeytinburnu ilçesi Sümer Mahallesi Kentsel Dönüşüm Projesi'nin yaşayanlar üzerindeki etkisi kentsel 
dönüşümde sosyal etki değerlendirmesi bağlamında irdelenmiş ve kentsel dönüşüm çalışmalarına yön verecek sonuçlar tartışılmıştır.

\section{Materyal ve Metot}

Makale literatür araştırması ve alan çalışması olmak üzere iki aşamada, nicel ve nitel değerlendirmeleri içeren karma bir metodoloji ile kurgulanmıştır. Çalışmanın temel materyallerini internet, kütüphane taramaları ile elde edilen makale, tez, kitap vb. yerli ve yabancı kaynaklar, İstanbul Büyükşehir Belediyesi, Zeytinburnu Belediyesi ve saha araştırmalarından elde edilen haritalar, planlar, raporlar, yazılı ve görsel kaynaklar oluşturmaktadır. Kentsel dönüşüm ve sosyal etki değerlendirmesine yönelik literatür çalışmasının akabinde, İstanbul kenti Zeytinburnu ilçesi Sümer Mahallesi Kentsel Dönüşüm Projesi örnekleminde alan çalışması yapılmıştır. Zeytinburnu ilçesinin sosyal, ekonomik, kültürel ve mevcut yapı özellikleri açısından karmaşık bir doku içermesi ve bu sebeple dönüşüm potansiyelinin yüksek olması, ve İstanbul Deprem Master Planı (IDMP), JICA (Japon Uluslar arası İşbirliği Ajansı) ve İBB (İstanbul Büyükşehir Belediyesi) tarafından hazırlanan raporlar doğrultusunda, Zeytinburnu ilçesinin Pilot Bölge seçilmesi ve AB uyum programları çerçevesinde İstanbul'a özgü değerlerin korunarak daha güvenli ve yaşanabilir mekânlar oluşturmak için yapılacak uygulama projesinin Zeytinburnu ilçesinde başlanmış olması, plan ve proje bilgilerine zorluklarla karşılaşmadan erişilebilecek olması nedenleriyle İstanbul kenti, Zeytinburnu ilçesi, Sümer Mahallesi kentsel dönüşüm projesi çalışma alanı olarak seçilmiştir.

Sosyal etki değerlendirmesi için Sosyal Etki Tasarımı Rehberi Yöntem Kartlarından (URL1, 2019; Kentsel Strateji, 2014), "Bina, Sokak, Mahalle Yöntemi” çerçevesinde yazar tarafından geliştirilerek oluşturulan kartlar kullanılarak, dönüşüm alanında yaşayan kişilerle derinlemesine görüşmeler gerçekleştirilmiştir. Bu makalede, sokak ve mahalle kartlarının değerlendirmelerine yer verilmiştir. Görüşme kartları, kentsel dönüşümün sosyal etkisini 3 farklı zamana ait (dün-bugün-yarın özelinde) ve 3 farklı değişime (mekânsal, yaşamsal ve ekonomik bakış) yönelik olarak değerlendirmeye odaklanmaktadır.

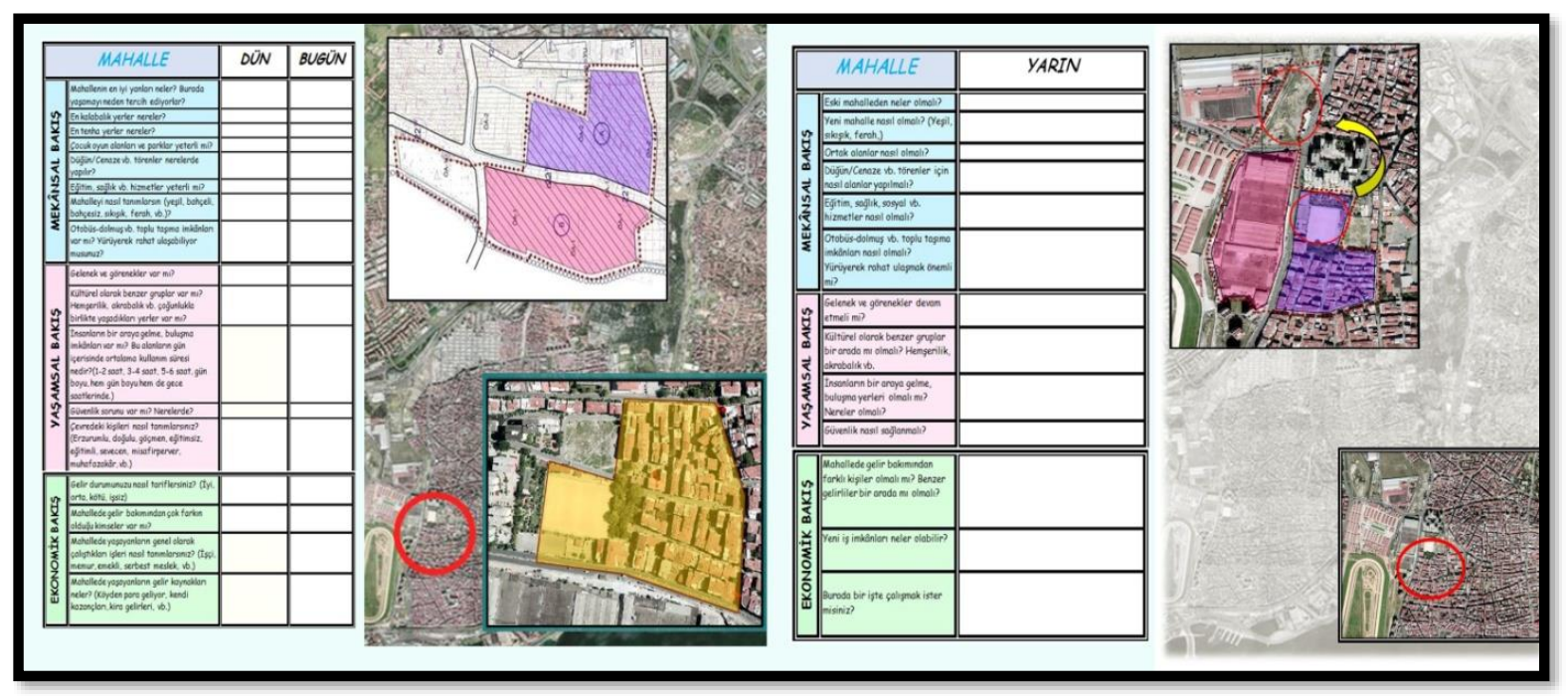

Şekil 1. Mahalle kartı

Mahalle kartı (Şekil 1) ile mahallenin karakterini ve dinamiklerini anlama, yeni yaşama dair fikirleri öğrenme, mevcut yaşam alışkanlarındaki olası değişikler hakkında farkındalık durumuna yönelik sorularla yaşayan sokak ölçeğine yönelik değerlendirmeler, yenilenen doku, mevcut alanlarda yaşam düğümü ve can damarı olan yerler, sosyal anlamda değişim ve etkilerine yönelik sorularla bizim mahalle ölçeğine yönelik değerlendirmeler gerçekleştirilmiştir. Sokak kartında (Şekil 2) ise; mevcut sokak kullanımı ve olası sokak tipolojileri hakkında fikirleri alma ve dar ve geniş sokakların olumlu ve olumsuz yanları hakkında farkındalık durumuna yönelik sorularla uyumlu bina ölçeğine ilişkin değerlendirmeler gerçekleştirilmiştir. Mahalle kartında 30 ve sokak kartında ise 30 soru bulunmaktadır. 

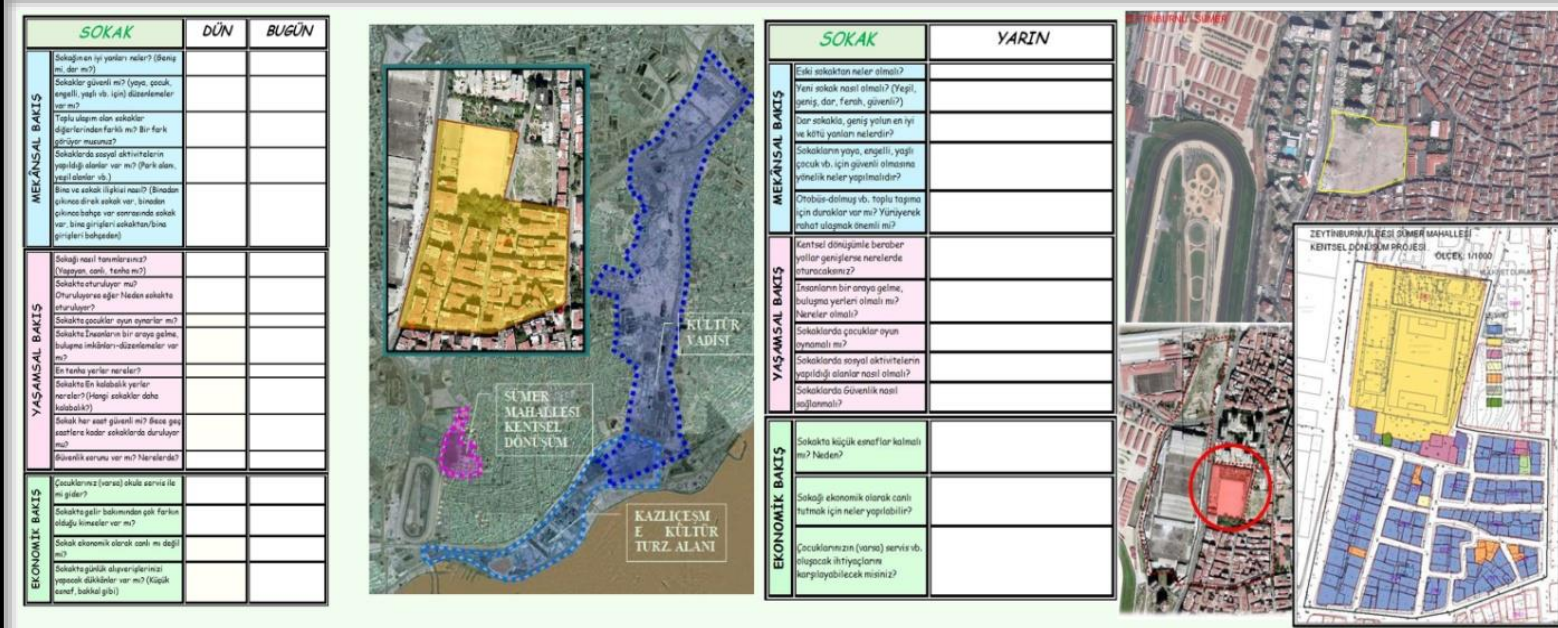

Şekil 2. Sokak kartı

“Bina, Sokak, Mahalle Yöntemi” projeden etkilenenler perspektifinden dünün izleri, bugünün alışkanlıkları ve yarın için beklentileri çerçevesinde sosyal etki değerlendirmesinde yol gösterici bir yöntemdir.

\section{Bulgular ve Tartışma}

\subsection{Sümer Mahallesi Kentsel Dönüşüm Projesi Sosyal Etki Değerlendirmesi}

Zeytinburnu ilçesi; İstanbul Metropoliten alanı batı yakasında Trakya'nın güneydoğusunda, Çatalca Yarımadasının, Marmara Denizine bakan yamaçlarında yer almaktadır (URL 2, 2019) (Şekil 3). İBB ile JICA tarafindan yapılan araştırma sonuçlarına göre Zeytinburnu'nun 13 mahallesinden 6'sının riskli alan olarak belirlenmiştir. Bunlar; Seyitnizam Mahallesi, Beştelsiz Mahallesi, Çırpıcı Mahallesi, Veliefendi Mahallesi, Gökalp Mahallesi ve Sümer Mahallesidir.

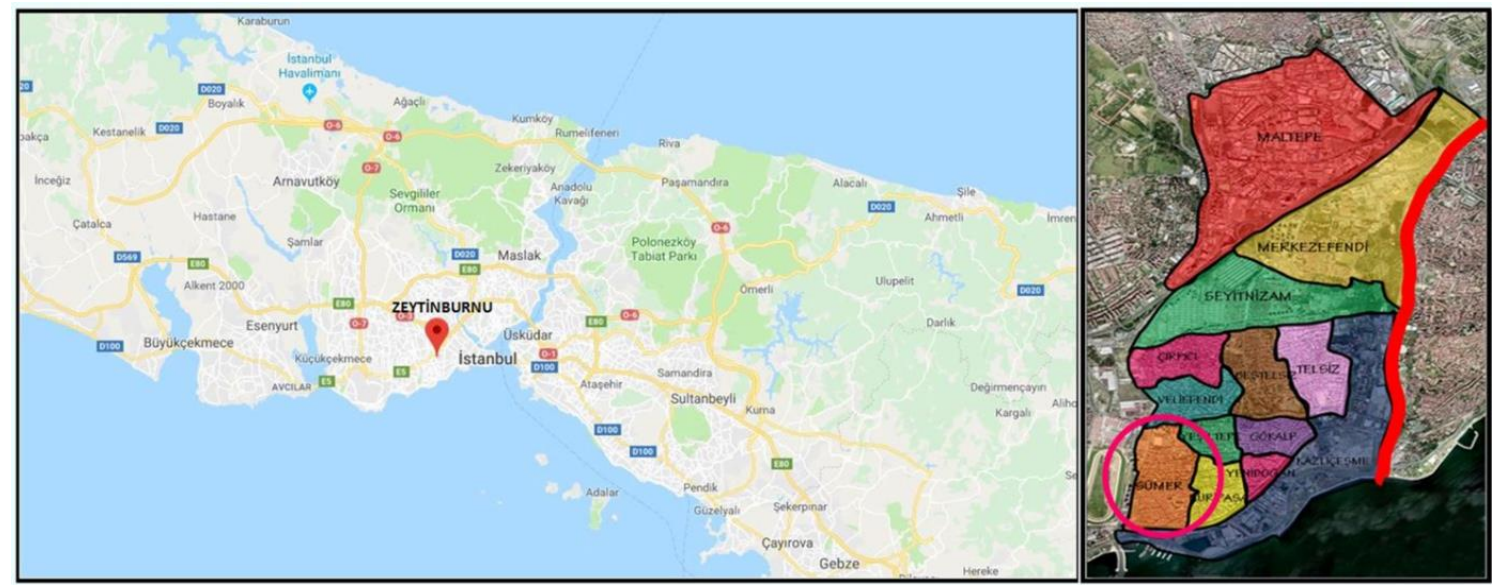

Şekil 3. Zeytinburnu ilçesi konumu (http://sehirharitasi.ibb.gov.tr/ adresinden konum resmi kullanılarak yazar tarafından düzenlenmiştir.)

5393 sayılı Belediye Kanunu'nun 73. Maddesi kapsamında ilçe bütününde dönüşüm potansiyeli taşıyan ve kentsel dönüşümü tetikleyebilecek alan olarak öngörülen Sümer Mahallesi, kentsel dönüşüm olarak belirlenmiş ve bu alanda çalışmalar devam etmektedir (Şekil 4, 5). Dönüşümün Sümer Mahallesi'nde başlamasının temel nedeni; dönüşüm potansiyelinin ve yoğunluğun yüksek olması, gecekondulaşma ve çarpık kentleşmenin ilk odağı olması ve ilk etapta yapılacak konutlar için boş alanın olmasıdır. 


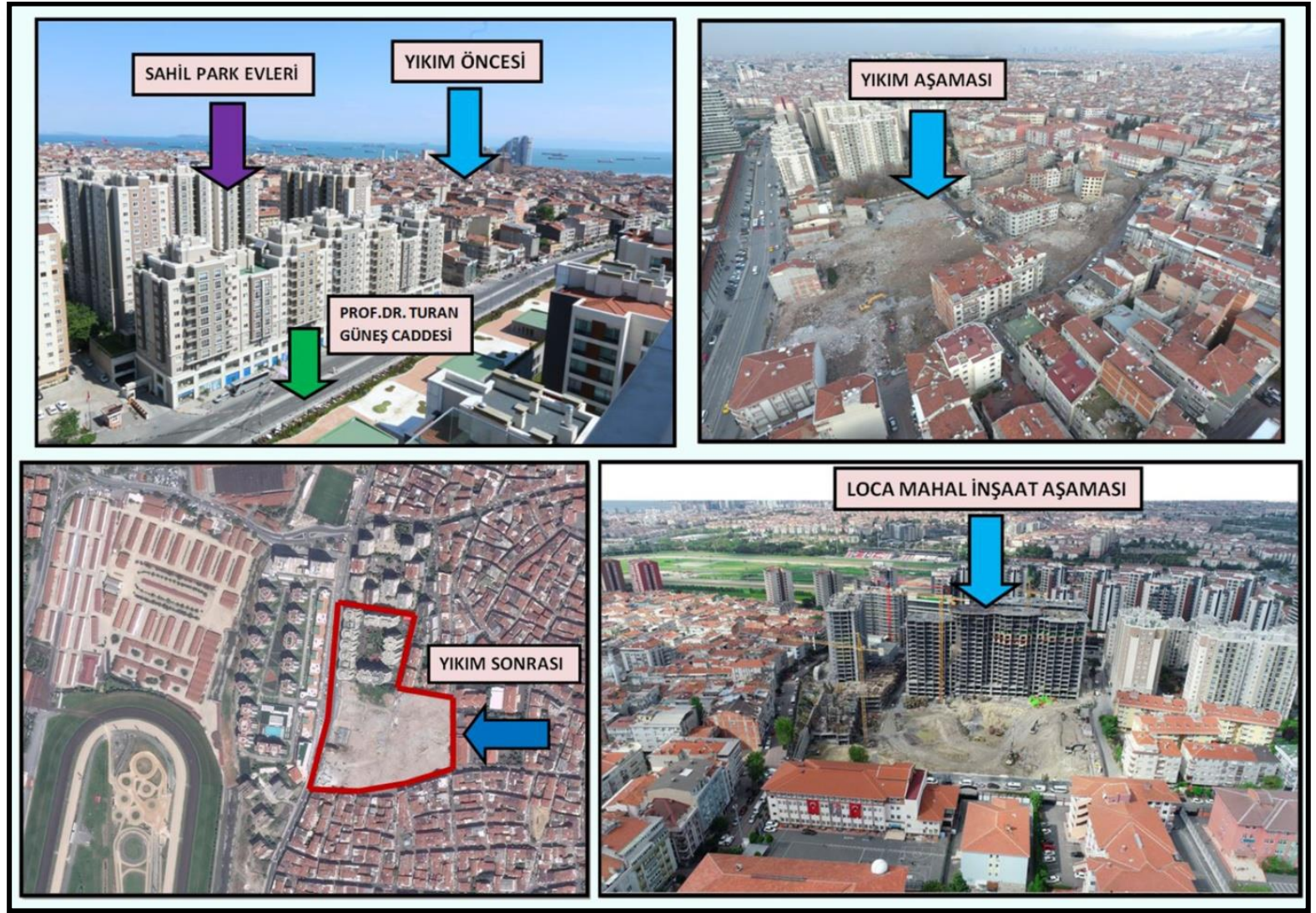

Şekil 4. Dönüşüm alanı ve değişimi (KİPTAŞ, 2019 yılı alınan fotoğraflar yazar tarafından düzenlenmiştir.)

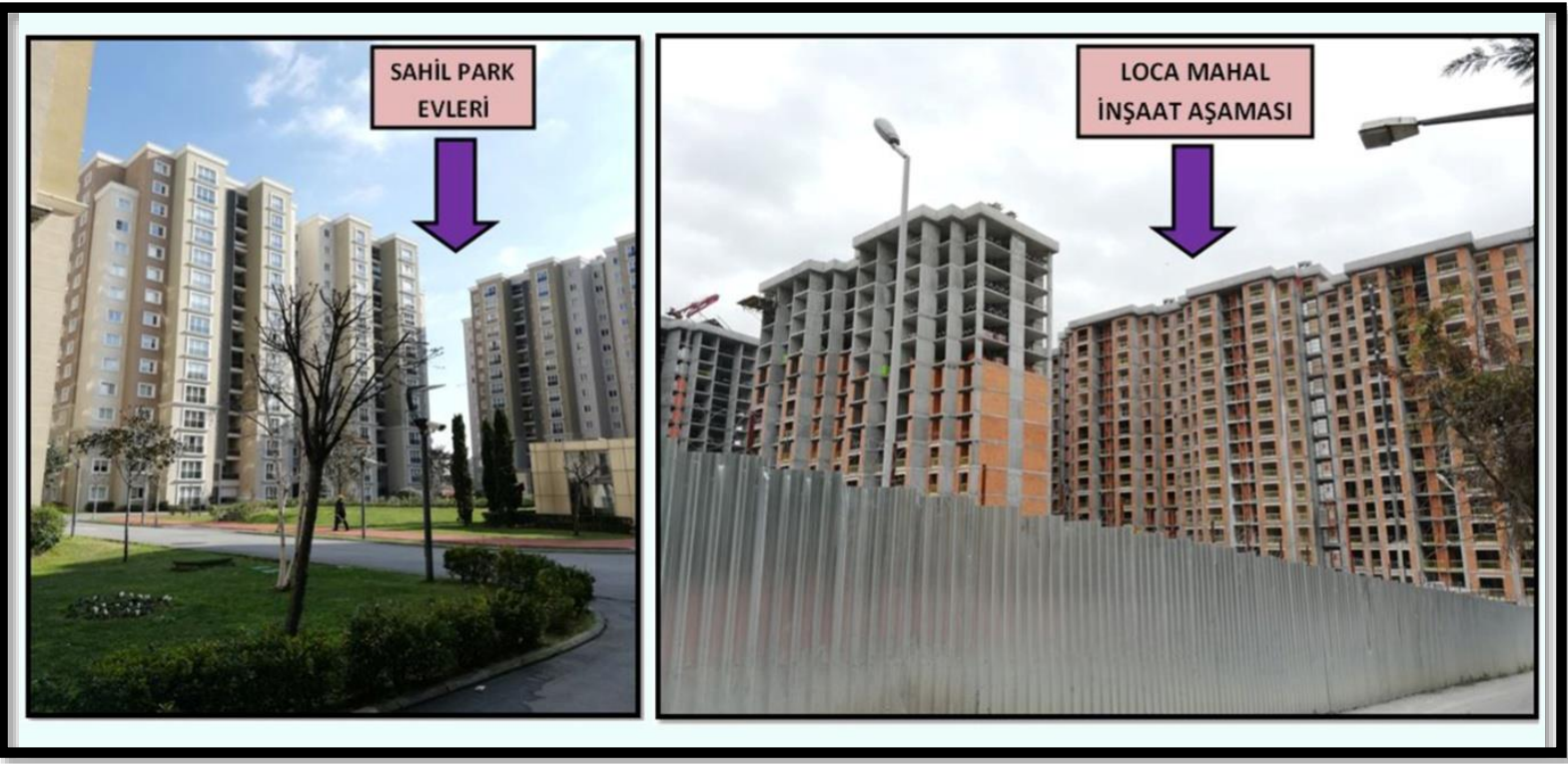

Şekil 5. Dönüşüm alanının görüntüsü (Fotoğraflar yazar tarafından 2019 yılında çekilmiştir.)

Proje iki aşamadan oluşmaktadır. Birinci aşamada Spor Sahası alanına Sahil Park evlerinin yapılmasıyla başlanmış ve tamamen bitirilmiştir. Birinci aşaması gerçekleştirilmiş, ikinci aşaması ise yıkım işlemleri tamamlanmış inşaat aşaması devam etmektedir. İnşaatı devam eden sahada oturan kişilerin bazıları Sahil Park Evlerinde konut sahibi olarak veya kira yardımı alarak yaşamlarına devam etmekte, ikinci etabın bulunduğu alanda yaşayanların bazıları ise dönüşüm süreci için yakın çevrede geçici olarak kiralık başka konutlara yerleştirilmiştir. İkinci etabın gerçekleştirileceği alanda yaşayanlara ulaşabilmek ve derinlemesine görüşmeleri gerçekleştirebilmek için projeyi gerçekleştiren KİPTAŞ (İstanbul Büyükşehir Belediyesi’ne bağlı Konut İmar Plan Sanayi ve Ticaret Anonim Şirketi) ile iletişime geçilmiştir. Elde edilen bilgiler çerçevesinde 2019 yılı ocak 
ve şubat aylarında 27 adet yüz yüze derinlemesine görüşme gerçekleştirilmiştir. Görüşmeler yaklaşık olarak 45 dakika 1 saat aralığında sürmüş, kişilerin yoğun ilgisinden dolayı bazı görüşmeler 2 saatte tamamlanmıştır.

Projenin ikinci etabın eski sakinlerinden olup projenin birinci etapta tamamlanan konutlarda ikamet eden veya başka yerlerde ikamet eden çeşitli meslek gruplarından (mefruşatçı-perdeci- tekstil işleriyle uğraşan, pazarlamacı, dükkân sahipleri, yazar, bakkal, berber, esnaf, emlak sektörü, emekli, müteahhit, marangoz ve ev hanımı gibi) 27 kiși ile derinlemesine görüşmeler yapılmıștır. Görüşülen kișilerin 18'i erkek, 9'u kadındır. Görüşülen kişilerden 11 'i ilkokul, 5'i ortaokul, 7 kişi lise ve 4'ü de ön lisans mezunudur. Görüşülen kişilerin 5'i 24-35, 6’sı 36-44, 9'u 45-55, ve 7'si 56 ve üzeri yaş aralığındadır.

\subsection{Mahalle Kartlarının Değerlendirilmesi}

\section{Mekânsal bakıșa yönelik dün- bugün özelindeki değerlendirmeler așağıdaki gibidir.}

Mahallenin en iyi yanları nelerdir? Sorusuna Sümer Mahallesi’nde yaşayan, görüşme yapılan kişiler komşularının birbirinin tanıdığı olması ve mahallede aidiyet duygusunun yoğun olarak yaşanmasını söylemişlerdir. Ancak, kentsel dönüşüm sürecinde, bazı kişilerin maddi zorluklardan dolayı mahalleden göçmek zorunda kaldıkları da görülmüştür.

"Doğma büyüme burada olduğumuz için ve eş, dost, akraba, yerli halkı tanıdığımız için burada yaşıyordum. Fakat mahallemiz kentsel dönüşüme girdikten sonra belli ekonomik seviyede olan yakınlarımız, eş-dostlarımızın yaşam standartlarından dolayı göç ettiklerini gördük.” [G1: (E, 53), mefruşat-perde işiyle meşgul, dükkân sahibi, doğma büyüme mahallede yaşayan yerel sakin]

Relph (1976)'e göre “bir yer içinde olmak, ona ait olmak ve onunla özdeşleştirmek”tir. Komşuluk ve toplumun sosyo-mekânsal yorumu, buralarda yaşayan halkın sahip olduğu bağları kabul etmektedir. Bu genellikle topluluk hissi olarak tanımlanır (Kearns ve Forrest, 2000; Dempsey vd., 2011). İnsanlar kentle kurdukları ilişki ile kentin bir parçası olurlar. Mahalle yalnızca fiziksel bir birim olmayıp bir birlikteliktir. Mahalleyle kurulan ilişki, kişinin mahallesiyle ve yaşadığ yerle kurduğu aidiyet ve kimlik ilişkisini belirler. Belirli bir mahallede oturmak ve oradaki gündelik hayat biçimini yaşamak demektir (Duman, 2014).

Mahallede tanınır, bilindik olmak önemlidir. Mahalleye dışarıdan giren yabancı fark edilir. Herkes mahallede kimlerin oturduğunu bilir. Çeşitli derecelerde de olsa herkes birbirini tanır (Duman, 2014). İnsan ile mekân arasında bir iletişim ve karşılıklı etkileşim vardır. İnsanoğlu bir mekânda geçirdiği süreyle doğru orantılı olarak mekân ile kendisi arasında aidiyet üzerine bir bağ kurmaya başlar. Oluşan bu bağ neticesinde insan mekânı özümser ve ona farklı anlamlar yüklemeye başlar. Tüm bunların neticesin de mekân sadece mekân olmaktan çıkar, güvenin, samimiyetin, korkunun, sevincin, hüznün, dostluğun, komşuluğun ve özgürlüğün bir görünümüne bürünür (Dur, 2015).

"Komşularımızla iç içeydik. Herkes birbiriyle yardımlaşmayı severdi. Yabancı kimse yoktu. Şu an kimse birbirini tanımıyor. Çoğu kişi evlerini satıp gitti.” [G5: (E, 26), perdeci, doğma büyüme mahallede yaşayan yerel sakin]

"İnsanlar birbirini tanıdı̆̆ iç̧in yardımlaşma yoğun yaşanıyordu. İnsan ayrımı yoktu. Komşuculuk yardımlaşma vardl. Fakat kentsel dönüşüm gelince insanlar bu süreçte taşınanlar oldu ve kopuşlar yavaş yavaş başladı." [G3: (E, 57), yazar ve mefruşat-perde işiyle meşgul dükkân sahibi, Urfalı, 1977’ten beri mahallede yaşayan yerel sakin]

Mahallenizde düğün/Cenaze vb. törenler nerelerde yapılır? Sorusuna cevap olarak, eski mahallede yaşayanlar, önceden düğün, kına, asker eğlenceleri gibi törenleri mahalleliyle yardımlaşarak yaptıklarını ve bu eğlencelerin sokaklarda, kapı önlerinde olduğunu ve sokak kültürünün eskiden daha yoğun olarak yaşandığını belirtmektedir. Zamanla mahalle kültürünün yok olmaya başlamasıyla bu gibi kültürlerinde yok olduğu yaşananlar arasındadır.

"Kınalar falan sokaklarda yapılırdı. Sonradan yasaklandı. Kürtler yapardı daha çok. Dönüşüm sonrası sokak kültürü yok oldu. Sokaklardan uzak kaldık. Çıkıyorum sokakta çöp arabası görünce tuhaf oluyorum artık sen düşün. ” [G26: (K, 41), ev hanımı, 22 yıldır mahallede yaşayan yerel sakin]

"Önceden dügü̈n için bir toplanma yeri yoktu. Salon tutuluyordu. Asker eğlenceleri kapı önünde yapıllyordu. Taziye yerleri kendi evlerinde oluyordu ama herkes birbirini tanıyordu. Artık kimin öldüğ̈̈ bile bilinmiyor.” 
[G20: (K, 62), ev hanımı, Osmaniyeli, 25 yıldır mahallede yaşayan yerel sakin]

\section{Mekânsal bakıșa yönelik yarın özelindeki değerlendirmeler așağıdaki gibidir.}

Komşu, insanlara ailesinden sonra, mekânsal açıdan da en yakın olandır. Güvenilir olması, zorda kalınınca hiç düşünmeden kapısının çalınabilir olması, kendisinde zarar gelmeyeceğine inanılması bunlardan ilk akla gelenleridir (Dur, 2015). Mahalle yaşamında kişinin en yakınları ailesiyle sınırlı olmamakla birlikte kişinin komşuları da bu sevgi çemberini oluşturmakta birinci derecede etkilidir (Duman, 2014).

Eski mahalleden neler olmalı? sorusunda kişiler eski mahallelerindeki komşuluk ilişkilerinin iyi düzeyde olduğu, oradaki samimiyetin, sokak kültürünün, komşuluğun aynen devam etmesini istediklerini belirtmişlerdir.

"Eski komşularım olsaydı iyi olurdu ama olacaklarını zannetmiyorum. Çünkü kira gibi aidat isteyecekler. Imkânı olmayan da gelemeyecek. Aidatlardan dolayı ben bile gelmek istemiyorum. Kiracı gibi olacağız kendi evimizde." [G9: (E, 50), perdeci, 25 yıldır mahallede yaşayan yerel sakin]

"En başta oradaki insanlık olmalı. A ğaç, bă̆lar vardı eskiden. Incir- armut ăgaçları vardı onların olmasını isterdim.” [G11: (E, 52), pazarlamacı, Beyazıtlı 1975 yılından beri mahallede yaşayan yerel sakin]

Kamusal alanlar, tüm insanların kullanımına açık, sosyal ve fiziksel faaliyetin gerçekleştiği ortak kullanım alanlarıdır (Yıldız, 2016). Kamusal alanların ortak birtakım temel nitelikleri olup öncelik olarak hareketlilik ve erişimin var olması gereken alanlardır. Bu alanlar yayaların, engellilerin hizmetlere ve donatı alanlarına erişimini sağlayan, bekleme, toplanma, ayrılma, buluşma gibi faaliyetlerin gerçekleştirdiği hareket ve sosyal aktiviteleri gerçekleştirmede birincil alanlardır (Gökgür, 2008). Bir yerleşmenin algılanan güvenliğinin, sosyal sürdürülebilirliğin temel bir parçası olduğu kuramsal tartışmaların merkezinde bulunmaktadır (Barton, 2000).

Yeni mahalle nasıl olmalı? Ortak alanlar nasıl olmalı Düğün/Cenaze vb. törenler için nasıl alanlar yapılmalı? Sorularına görüşülen kişiler, kentsel dönüşüm sonrasına yönelik, yeni mekânda ortak alanlar da ferah ve yeşil alanlarının fazla olması, rahat, aydınlık ve kullanışlı ve güvenilir, güvenlikli alanlar tasarlanmasını istedikleri şeklinde cevaplar vermişlerdir.

"Ferah ve havadar olmall, kahveler olmall. Herkesin gidebileceği şekilde fiyatlar uygun olmall. Bir çay 5-10 TL olmamalı, uygun olmalı.” [G5: (E, 26), perdeci, doğma büyüme mahallede yaşayan yerel sakin]

"Yeşil alanı olmalı, oturma alanları ve çardaklarda da masa olmall. Şu an ki site de yok.” [G26: (K, 41), ev hanımı, 22 yıldır mahallede yaşayan yerel sakin]

“Çocuk oyun alanları ve güvenli alanların olduğu yerler olmall.” [G27: (K, 30), ev hanım1, 20 yıldır mahallede yaşayan yerel sakin]

\section{Yașamsal bakıșa yönelik dün-bugün özelindeki değerlendirmeler așağıdaki gibidir.}

Kültürel olarak benzer gruplar var mı? Hemşerilik, akrabalık vb. çoğunlukla birlikte yaşadıkları yerler var mı? Çevredeki kişileri nasıl tanımlarsın? Sorularına verilen cevaplara göre mahallede kültürel olarak benzer grupların bulunmaktadır; Karadeniz, Trakya ve Doğu kesiminden daha fazla kişilerin olduğu belirtilmiştir. Her kesimin kendine ait derneği olup dayanışma, yardımlaşma içerisinde oldukları ve gelenek ve göreneklerin yaşatılmasında herkesin ayrı katkısının bulunduğu görüşü önem taşımaktadır.

“Karadenizliler ve göçmenler vardı bizim mahallede. ... Bazıları gitti, bazıları kaldı. Zaman zaman göçlerle evlerde kiraya verildi. Mevcuttaki yaşam alanının kalitesi de düştü. Yıkıldıktan sonra ondan da kurtulmuş olduk. Eskiden herkes birbirine yardım ederdi. Kentsel dönüşüm söylentileri başladı, sözleşmeler, anlaşmalar başladı ve o kültür buradan insanlarla birlikte göç etti gitti. ...” [G1: (E, 53), mefruşat-perde işiyle meşgul dükkân sahibi, doğma büyüme mahallede yaşayan yerel sakin]

Sosyal etkileşim olmadan, belirli bir bölgede yaşayan insanlar, topluluk hissi veya yer duygusuyla ayrı yaşamları olan bir grup birey olarak tanımlanabilir. Bireyler, aileler ve topluluklar gibi farklı sosyal ortamların organizasyonu, belirli bir mahallede yaşayanların davranışları, değerleri ve kimlikleri, güven duygusu ve esenlik duygusu gibi yaşamın diğer yönlerini etkileyebilmektedir (Dempsey vd., 2011). Mahallenin en önemli özelliklerinden biri de komşuluk ve komşuluk ilişkileridir. Konu-komşudur mahalleli; insanın yakınında olan, çağırdığında sesine yetişecek, yardım eli uzatacak kadar yakınındakilerle beraber inşa edilen toplumsal bir ortamdır. Bu yüzden mahallede faaliyetler dayanışma, komşuluk, yardımlaşma, ortak çözümler ile birlikte 
yerine getirilir (Alver, 2010).

Gelenek ve görenekler var mı? İnsanların bir araya gelme, buluşma imkanları var mı? Güvenlik sorunu var mı? Nerelerde? Sorularına verilen görüşlere göre mahalledeki kişilerin komşuluk ilişkilerinin çok iyi olması, ortaklaşa yapılan işlerin olması, insanların birbirlerini gördüklerinde sohbetlerin edilmesi ve güvenmesi komşuluk kültürünün üst düzeyde yaşandığının göstergesidir. Ancak görüşülen kişiler bu kültürlerin sonrasında yok olduğunu söylemişlerdir. Eski mahallede insanların sokaklarda, apartman önlerinde buluşup bir araya geldikleri, buralarda sohbetlerin yapıldığı ve genelde iş çıkışları, akşamüstü daha çok hareketliliğin olduğu belirtilmiştir.

"Vardı. Mahallede otururduk çekirdek çitlerdik. Top oynardık komşuluk ilişkileri iyiydi. Top oynarken su istesek verilirdi. .... Herkes sıcakkanlıydı, yardımcı oluyorlardı." [G6: (E, 29), emlakçı, doğma büyüme mahallede yaşayan yerel sakin]

"Mahallede sinemalar vardl. O zaman da o sinemalar 3,5 lirayd, ucuzdu. Sinemalar șimdi A.V.M' lerde. Çay bahçeleri vardl. Her yer yeşil, ortalarda süs havuzları vardı. Her gün buluşulurdu. Mahallede saat 12 de bile buluşurduk." [G4: (E, 38), bakkal, doğma büyüme mahallede yaşayan yerel sakin]

Günümüzün hareketli yaşamında, insanlar artık daha önceki komşuluk duygusunu beklemeyerek iş, rekreasyon, arkadaş, mağaza, eğlence gibi unsurlar seçebilir ve süreç içinde ait olmak istedikleri toplulukları oluşturma sürecine girebilirler (Carmona vd., 2003). İnsanların geçmişte yaşanan mahalle ilişkilerine duydukları özlem mahalle kültürünün yok olmaya başlamasıyla beraber başlamıştır. Çünkü günümüzde gerek insanların iş hayatında geçmişe nazaran daha fazla yer almaları (özellikle kadın istihdamı olarak) gerekse de aynı apartmanda yaşasalar bile insanların farklı kültürel, ekonomik ve sosyal kültürlere sahip olması ister istemez bir ayrışma meydana getirmektedir (Dur, 2015).

Yaşamsal bakısa yönelik yarın özelindeki değerlendirmeler aşağıdaki gibidir.

Gelenek ve görenekler devam etmeli mi? Kültürel olarak benzer gruplar bir arada mı olmalı? Sorularına verilen görüşler değerlendirildiğinde, mahallede yaşayanlar, eski gelenek ve göreneklerinin, komşuluk kültürü, sokak kültürü gibi değerlerin sürdürülmesini istemektedirler. Ancak, bazı kişilerin bu kültürlerin devamını istedikleri ancak yeni yapılanmada bunların devam edemeyeceği görüşünde oldukları belirlenmiştir.

“Türkün gelenek ve görenekleri Atalardan, Peygamberlerden gelmiş bunlar tabi ki devam etmeli." [G4: (E, 38), bakkal, doğma büyüme mahallede yaşayan yerel sakin]

"Etmeli ama eski mahallemizden çoğu kişi yeni sitelere taşınmayacaklarını söylüyorlar. Herkes gitti, gidecek. Kimse kalmayacak devam edeceğini pek sanmiyorum o yüzden." [G5: (E, 26), perdeci, doğma büyüme mahallede yaşayan yerel sakin]

Güvenlik nasıl sağlanmalı? Sorusunun değerlendirmesinde mahallede güvenliğin herkesin birbirini tanıyıp güvenmesiyle olabileceği düşünülmektedir.

"Herkesin birbirini tanıyıp, güvenmesi ile sağlanmalı. Sorun çözülür böylece. Dükkânımın orada kavga çıkıyor biz ayırsak bitiyor." [G6: (E, 29), emlakçı, doğma büyüme mahallede yaşayan yerel sakin]

"İnsanlarda başlamalı güvenlik bilinci. Her insanın başına polis dikemezsin. Her insan bir sıkıntı yaşayan insana, diğerleri yardım ediyorsa güvenlik başlamıştır." [G9: (E, 50), perdeci, 25 yıldır mahallede yaşayan yerel sakin]

Günümüz güvenlikli sitelerinde duvarlar sanki bir sur görevi görmektedir. Bu durum komşuluk ilişkilerinin zayıflamasına neden olmaktadır. Günümüz apartmanlarının kat sayısı arttıkça içerisinde yaşayan insanların sosyal ilişkileri ve komşuluk ilişkileri de o derece azalmaktadır (Dur, 2015).

\section{Ekonomik bakışa yönelik dün-bugün özelindeki değerlendirmeler așağıdaki gibidir.}

Gelir durumunu nasıl tariflersin? Mahallede gelir bakımından çok farkın olduğu kimseler var mı? Mahallede yaşayanların genel olarak çalış̧ıkları işleri nasıl tanımlarsın? Mahallede yaşayanların gelir kaynakları neler? Sorularına verilen görüşler, mahallede yaşayanların gelir durumlarının eskiden iyi düzeyde olduğu ancak kentsel dönüşümden sonra bu durumun kötüleşmeye ve yeni gelen ekstra maliyetler karşısında yetersiz kalmaya başladıkları sonucunu göstermektedir. Mahallede yaşayanların gelir durumu ile ilgili olarak yapılan 
değerlendirmede genel olarak gelir düzeyinin orta seviyede olduğu, gelir bakımından çok farkın olmadığı ama mahallede bazı zengin kesimin de bulunduğu ve memur, işçi ve esnafların çoğunlukta olduğu söylenmiştir.

“Dönüşüm başlayınca yerimizi bıraktıktan sonra ... ticari edinim ve birikimlerimizin aşağıya düşerek ... ticari kar etkinliğimiz \%50 oranında azaldı. Müşteriler kaybedildi. Perdeciler Çarşısı yok oldu. ... Mevcut alanın, çarşının devam etmesi lazım." [G1: (E, 53), mefruşat-perde işiyle meşgul, dükkân sahibi, doğma büyüme mahallede yaşayan yerel sakin]

"Eskiden çok iyiydi. Kentsel dönüşümden sonra kötüleşmeye başladı. ... İşçi kesimi daha çoktu. Fabrikalar çoktu orada çalışıyorlardı.” [G10: (E, 58), emlakçı, Rizeli, 1982 yılından beri mahallede yaşayan yerel sakin]

"Memur, esnaf ve işçiydi önceden.” [G21: (K, 54), ev hanımı, Bakırköylü, 20 yıldır mahallede yaşayan yerel sakin]

Ekonomik bakıșa yönelik yarın özelindeki değerlendirmeler așağıdaki gibidir.

Mahallede gelir bakımından farklı kişiler olmalı mı? Benzer gelirliler bir arada mı olmalı?

Burada bir işte çalışmak ister misin? Sorusu için görüşülen kişiler, mahallede gelir bakımından farklı kişilerin karışık olması gerektiği, bu farklılıklar sebebiyle insanların birbirine yardım ve kaynaşmayı artıracağı şeklinde düşünmektedir.

"Yardımlaşma için farklılık gerekli. Biz yardım ederken zorlanmıyorduk." [G21: (K, 54), ev hanımı, Bakırköylü, 20 yıldır mahallede yaşayan yerel sakin]

Yeni iş imkânları neler olabilir? Sorusu için mahallede kentsel dönüşümden sonra oluşacak yeni yapılanmada iş imkânları olarak eskiden beri yapıla gelen mefruşat, perde sektörünün devamının sağlanması gerektiği, eski esnafların desteklenmesinin istendiği belirtilmiştir.

"Doğal olarak zaten mevcut yapılanmadan sonraki ticarethanelerin eski stralı mefruşat măgazası (perdeci) olması zor ihtimal. İş yerlerinin kira gelirlerinin daha fazla olacă̆ını düşünerek farklı iş alanlarındaki marka dallarının gelip burada ticaret yapmalarına sebep olacak. Gıda üzerine, mobilya, banka hizmetleri üzerine iş imkânları çeşitlendirilebilir.” [G1: (E, 53), mefruşat-perde işiyle meşgul dükkân sahibi, doğma büyüme mahallede yaşayan yerel sakin]

"Ev hanımları için ürettiklerini, yaptıklarını satacă̆ı yerler olmalı.” [G24: (K, 63 yaşında), ev hanımı, 60 yıldır mahallede yaşayan yerel sakin]

\subsection{Sokak Kartlarının Değerlendirilmesi}

Mekânsal bakıșa yönelik dün-bugün özelindeki değerlendirmeler așağıdaki gibidir.

Sokak kartlarından mekânsal bakışa yönelik görüşmelerde dün- bugün özelinde genelde insanların farklı şeyleri söylediği görülmüştür.

Sokağın en iyi yanlarının ve yaya, çocuk, engelli, yaşlı vb. için düzenlemelerin varlığına ve güvenliğine ilişkin yöneltilen sorularda mahalle sakinlerinin eski sokakları güvenli bulduğu, sokaklarda yaya, engelli, yaşlı, çocuk vb. için herhangi bir düzenlemenin olmadığı belirtilmiştir. Kentsel dönüşümle suç olaylarının arttığ1 düşünülmektedir.

"Eskiden güvenliydi. Engelliler, yaşlılar, yayalar, çocuklar vb. için herhangi bir düzenleme yoktu sokaklarda. Kentsel dönüşüm sürecinde güvenli değildi sokaklar. Uyuşturucu ile ilgili sorunlar yaşandı.” [G3: (E, 57), yazar ve mefruşat-perde işiyle meşgul dükkân sahibi, Urfalı, 1977’ten beri mahallede yaşayan yerel sakin]

"Güvenli değildi. Hiçbir düzenleme yoktu. Çoğu kişi taşındı. Binalar yıkıldl, harabe gibi oldu. Boşalan binalara Suriyeliler geldi oturdu." [G5: (E, 26), perdeci, doğma büyüme mahallede yaşayan yerel sakin]

Jacobs (1961) 'bir şehrin sokaklarının yabancıların fark edilmesi ve güvenliğin sağlanmasını kendiliğinden yapması gerektiğini' savunmaktadır.

Sokakların sosyal imkânlarla ve yeşil alanlarla ilişkisinin değerlendirilmesine yönelik olarak sorulan sokaklarda sosyal aktivitelerin yapıldığı alanlar var mı? Sorusunda görüşme yapılan kişiler, sokaklarda sosyal aktivitelerin yapıldığı alanların çok az olduğu veya hiç olmadığı, yapılaşmanın buna izin vermediği, boş alanlara bina yapıldı ̆̆ , park alanlarının uzakta olduğunu belirtmişlerdir.

“Top sahası vardı, şimdi ki Sahil Parkın olduğu yer, top sahası da taşındı. Park alanı yoktu.” [G3: (E, 57), 
yazar ve mefruşat-perde işiyle meşgul dükkân sahibi, Urfalı, 1977'ten beri mahallede yaşayan yerel sakin]

Kamusal toplanma alanları, toplumsal kimlik kültürünü pekiştirmek için kentin önemli ve erişilebilir noktalarında düzenlenmelidir (URL 3, 2019).

“Belli yerler vardl. Top sahasl, park, kahveler falan.” [G5: (E, 26), perdeci, doğma büyüme mahallede yaşayan yerel sakin]

“Önceleri pek yoktu. Yapılaşma bitişik nizam binalar yüzünden. Yapılan sitede içerisinde olacak deniliyor.” [G 21: (K, 54), ev hanımı, Bakırköylü, 20 yıldır mahallede yaşayan yerel sakin]

Sokakta, mekânsal bakışa yönelik dün bugün özelindeki değerlendirmeler, sokakta tanınır yüzlerin varlığının güvenlikli sokakları oluşturduğu, ancak kentsel dönüşüm süreciyle birlikte mekânda güven algısının giderek azalmaya başladığını göstermektedir. Değerlendirmelere göre dönüşüm öncesinde sokakların genel olarak geniş olduğu, canlı olduğu, otopark sorunu olmadığı bunların yanında komşuluğun üst düzeyde olduğu belirlenmiştir.

\section{Mekânsal bakıșa yönelik yarın özelindeki değerlendirmeler așağıdaki gibidir.}

Görüşme yapılan kişiler, dar sokakla, geniş yolun en iyi ve kötü yanları nelerdir? Sorusu için yeni yapılacak sokağın genişlemesine bağlı olarak erişilebilirliğinin artacağı ve eskisinden de daha iyi olacağı yönünde görüşler belirtilmiştir.

"Daha iyi olacağını düşünüyorum. Çünkü sokak genişleyecek. Dükkânlar depreme daha dayanıklı olacak. Sokak içinde arabaların çoğu için otopark ihtiyacı karşılanacağ için hem sokak ferah olacak hem otopark sıkıntısı olmayacak." [G3: (E, 57), yazar ve mefruşat-perde işiyle meşgul dükkân sahibi, Urfalı, 1977'ten beri mahallede yaşayan yerel sakin]

Eski sokaktan neler olmalı? sorusunda görüşme yapılan kişiler, eski sokaktan eski komşularını ve eski sokak kültürünün devamını istediklerini belirtmişlerdir.

"Şimdi sokak yok sokakta değiliz. Sitede oturduğumuz için. Eskiden sokağa poğaça satanlar gelirdi. Sepetle alırdık. Şimdi burada kime sallayacaksın sepeti.” [G20: (K, 62), ev hanımı, Osmaniyeli, 25 yıldır mahallede yaşayan yerel sakin]

"Pazarım olmalıydı, çocuklarım kapının önünde oynayabilmeliydi.” [G23: (K, 63), ev hanımı, Kırklarelili, 50 yıldır mahallede yaşayan yerel sakin]

Sokak; alışveriş, ulaşım, gezme vb. insanın toplumsal yönlerini, faaliyetlerini üzerinde gerçekleştirdiği alandır. İnsanlar sokak üzerinde diğer mahalle insanları ile iletişim ve etkileşime geçer. Sokak olmadan bu etkileşimlerin olması mümkün değildir. Bireyin sosyalleşmesinde de önemli katkıları olan sokak, bu özelliği ile kişiler arasında sosyal bir bağ kurar. Böylece sokak salt fiziksel olmanın ötesinde kültürel bir özellik kazanır (Alver'den aktaran Baday, 2011).

Sokağın mekânsal bakışına yönelik talepleri belirlemek amacıyla sorulan yeni sokak nasıl olmalı/olacak? ve Sokakların yaya, engelli, yaşlı çocuk vb. için güvenli olmasına yönelik neler yapılmalı? Soruları için görüşler, yaya, engelli, yaşlı, çocuk vb. için güvenli olmasına ve rahat yaşamalarına yönelik uygulamaların düşünülerek hayata geçirilmesi gerektiği şeklindedir.

"Engelliler için belirli standartların hepsinin uygulanması gerekir. Binadaki asansörlerde bile engelliler için düzenlemeler yapılması gerekir. Yaya, bisiklet yolları ona göre düzenlenmesi gerekiyor.” [G1: (E, 53), mefruşat-perde işiyle meşgul dükkân sahibi, doğma büyüme mahallede yaşayan yerel sakin]

"Yaya yolu yapılmalı, ışıklar konulmalı, sarı çizgili yollar, kaldırım taşlarına basarken hissedebileceği gibi düzenlenmeli. Engelliler de bu memleketin bir bireyi onlara da ayrım yapılmamalı.” [G6: (E, 29), emlakç1, doğma büyüme mahallede yaşayan yerel sakin]

Sokakta, mekânsal bakışa yönelik yarın özelindeki değerlendirmeler; yeni yapılaşmayla birlikte sokakta yaşayan eski komşuların gitmesi ve eski sokağa ait ticari fonksiyonların yok olmasıyla sokak kültürünün de eskisine nazaran yok olup gitmeye yüz tutacağı şeklindedir. Bununla birlikte dönüşümle yeni yapılacak sokakta her tür bireyin yaşamını kolaylaştıracak kullanımların düşünülmesiyle daha rahat, yaşanılabilir sokaklar oluşturulacağı beklenmektedir.

\section{Yașamsal bakıșa yönelik dün-bugün özelindeki değerlendirmeler așağıdaki gibidir.}

Sokak kartlarından yaşamsal bakışa yönelik görüşmelerde dün- bugün özelinde genelde insanların farklı 
gözlemleri olduğu görülmüştür. Kentsel dönüşüm sürecine girdikten sonra bugün özelinde yaşamsal bakışa yönelik sokakta değişiklikler olduğu belirtilmiştir.

Sokağı nasıl tanımlarsın ve sokakta en kalabalık yerler nereler? Soruları için sokakların çok canlı, hareketli ve yaşayan sokaklar olduğu, neredeyse hiç tenha sokak olmadığı, değişimden sonra sokakların eski canlılığını kaybettiği, sokakların tenhalaştı̆̆ söylenmiştir.

“Eskiden yaşayan, canlı bir sokaktı. Bakkal vardı. Dönüşümle birlikte canlılı̆̆ını bitirdi. Harabeye döndü.” [G3: (E, 57), yazar ve mefruşat-perde işiyle meşgul dükkân sahibi, Urfalı, 1977’ten beri mahallede yaşayan yerel sakin]

"Hareketliydi. Güzeldi. Insanlar gelip geçiyordu. Sonradan hareketlilik azald.. Evler boşaldı. Göçen gidenlerin yerine Suriyeliler oturmaya başladı. Terk edilmiş alan gibi oldu.” [G6: (E, 29), emlakçı, doğma büyüme mahallede yaşayan yerel sakin]

Sokak şehrin ve mahallenin damarı ve temel dokusudur adeta. Mahalle hayatının nirengi noktalarından birini oluşturur. Mahalleli sokaktan geçerek evine, işine gitmekte yahut toplumsal ilişkilerini sürdürmektedir. Sokağa çıkmadan toplumsal ortama katılmak imkânsızdır. Bütün mekânsal düzenlemeler için gerekli olan şey, sokak için de geçerlidir: sokak, sadece fiziki bir birim değil aynı zamanda toplumsal birimdir de (Alver, 2010).

Sokakta oturuluyor mu? Neden sokakta oturuluyor? Sorularının değerlendirmesi insanların sosyal aktivitelerini gerçekleştirebilecek nitelikte alanların olmamasından dolayı muhabbet, sohbetin yoğun olarak sokaklarda yapıldığı şeklindedir. Ancak, dönüşümle birlikte evlerin boşalması ve insanların taşınmasıyla birlikte bu kültürün de yavaş yavaş mahalleyi terk ettiği belirtilmiştir.

"Otururdu. Kadınlar otururdu, arka sokaklarda falan herkes otururdu. Kilim serip üzerinde çay içip sohbet ederlerdi. Herkes birbirine güvenirdi. Şimdi sokağa çocuğu salamıyoruz.” [G2: (E, 48), mefruşat-perde işiyle meşgul dükkân sahibi, Rizeli, 40 senedir mahallede yaşayan yerel sakin]

"Otururduk. Arkadaşlarla sohbet muhabbet ederdik. Balkondan bile konuşulurdu eskiden. Birbirine laf atardı herkes. İş çıkışları görüşürdük. Ya da okuldan çıkınca top oynardık. Stres atardık.” [G6: (E, 29), emlakç1, doğma büyüme mahallede yaşayan yerel sakin]

Mahallede kapının önünde oturmanın iki anlamı vardır. Birincisi kapı önleri insanların nefes ve hava almaları için bir imkândır. Para harcamadan, izin almadan sokağı yaşamaktır. İkinci olarak kapı önünde oturan kişiler diğer insanları gözler ve insanlar kendilerini gözetim ve baskı altında hisseder (Duman, 2014).

Sokakta çocuklar oyun oynarlar mı? Sorusuna yönelik görüşler, çocuklar için oyun alan yerlerinin olmamasından dolayı çocukların sokaklarda oyun oynadıkları şeklindedir.

“Evet, hep sokakta oynarlardı. Yer yok, oyun alanı yoktu.” [G20: (K, 62), ev hanımı, Osmaniyeli, 25 yıldır mahallede yaşayan yerel sakin]

Sokakta, yaşamsal bakışa yönelik dün bugün özelindeki değerlendirmeler, kentsel dönüşüm olgusunun insanların yaşamlarında büyük etkisi olduğu gibi sokaklarda da büyük etkiler göstereceği, eskiden canlı, hareketli, işlek, ruhu olan sokakların dönüşüm süreciyle birlikte yok olmaya başlama endişesinin olduğunu göstermektedir. Sokakların değişik faaliyetlerde kullanılması o sokağın ne kadar canlı ve hareketli olduğunu göstermektedir. Kadınların sokaklarda oturması, çocukların oyun oynaması, insanların birbiriyle görüşmesi yaşamsal olarak sokakların önemine işaret etmektedir.

\section{Yașamsal bakıșa yönelik yarın özelindeki değerlendirmeler așağıdaki gibidir.}

Kentsel dönüşümle beraber yollar genişlerse nerelerde oturacaksınız? Sorusunda görüşülen kişiler, kentsel dönüşümün getirdiği değişikliklerden biri olarak sokaklarda oturmaların devamının olmayacağı, yapılacak yeni yerin site şeklinde olacağından sokak diye bir şeyin kalmayacağını belirtmişlerdir.

"Yollar genişleyip oturma şansımız yok zaten. O kültür kayboldu. Böyle bir yapılanmanın üstüne böyle bir şey zaten olmaz." [G1: (E, 53), mefruşat-perde işiyle meşgul dükkân sahibi, doğma büyüme mahallede yaşayan yerel sakin]

"Mahallede otursan bile oturamıyorsun. O kültür bitti, yok zaten. Yabancılaşıyor. İnsanlar yadırglyor. Bu sistem ona itti. Adım başı kahveler var orada." [G6: (E, 29), emlakçı, doğma büyüme mahallede yaşayan yerel sakin]

Sokaklarda çocuklar oyun oynamalı mı? Sokaklarda sosyal aktivitelerin yapıldı̆̆ı alanlar nasıl olmalı? 
Sokaklarda güvenlik nasıl sağlanmalı? Sorularının değerlendirilmesinde çocukların günümüz şartlarında sokaklarda oynamaması gerektiği, sokakların her açıdan güvenli olmadığı ama eski sokakları gibi sokakları olsa oynamalarını istedikleri belirlenmiştir. Ayrıca eskiden oynandığı, sokakta tanıdıkların çok olduğu ve insanların birbirine güvendikleri belirlenmiştir.

"Şu an için oynamamall. Cadde eskisi gibi değil, güvenli dĕgil. Parklar oluşacak oralarda oynayacak. Çocuklar düşe kalka büyüyecek ama park göstermelik gerçi.” [G2: (E, 48 yaşında), mefruşat-perde işiyle meşgul dükkân sahibi, Rizeli, 40 senedir mahallede yaşayan yerel sakin]

“Ama eski sokağım gibi bir sokak olsaydı oynamasını isterdim.” [G23: (K, 63), ev hanımı, Kırklarelili, 50 yıldır mahallede yaşayan yerel sakin]

"Şu devirde oynamamal. İstismar, kaçırılma, uyuşturucu her şey var maalesef. Bunu da bu hale getirenler utansın. Insanın insana birbirine güveni yok artık. Çocuğunu sokağa gönderdiğinde insanların, tanıdıkların gözü üzerinde değilse zaten artık güven yok demektir. Eskiden öyleydi. Insanlar birbirine güvenmesiyle bile güvenlik sağlanabilir. Eskiden biz inerdik sokakta oynarken bize bakkal Ahmet amca bakardı mesela." [G6: (E, 29), emlakçı, doğma büyüme mahallede yaşayan yerel sakin]

Sokak alanının sosyal kullanımı için öncelikle çocuklara yönelik bir ortam yaratılması belirgin bir cazibeye sebep olmaktadır (Hamiduddin, 2015).

Sokakta, yaşamsal bakışa yönelik yarın özelindeki değerlendirmeler, kentsel dönüşüm sonucu kaybolan sokak kültürü ile eskiden yapılan faaliyetlerin yapılamayacağını, ancak bunların karşılanabileceği sosyal aktivite alanlarının oluşturulmasına yönelik çabaların varlığının önemli olduğunu göstermektedir.

\section{Ekonomik bakıșa yönelik dün-bugün özelindeki değerlendirmeler așağıdaki gibidir.}

Çocuklarınız (varsa) okula servis ile mi gider? Sorusunda mahallede yaşayan kişilerin çocuklarının çoğunluğunun yaya olarak okula gittikleri, çok az bir kesimin de servisle okula gittikleri söylenmiştir.

“Önceden servisle gidiyordu. Şimdi yürüyerek yakın okul.” [G14: (E, 50, mefruşatç1- perdeci, 45 yıldır mahallede yaşayan yerel sakin]

“Yürüyerek mahalledeki okula gidiyor. Kendimiz getirip götürüyoruz.” [G22: (K, 45), inşaat teknikeri ama çalışmıyor, Bahçelievler'den gelmiş, 40 yıldır mahallede yaşayan yerel sakin]

Sokakta gelir bakımından çok farkın olduğu kimseler var mı? Sokak ekonomik olarak canlı mı değil mi? Sokakta günlük alışverişlerinizi yapacak dükkânlar var mı? Sorularına verilen cevaplar, sokakların eskiden ekonomik olarak canlı olduğu, sokakta insanların ihtiyaçlarını karşılayabilecek her türden dükkânların olduğu, küçük esnafların da olduğu şeklindedir.

"Perdeciler Çarşısının hemen üstüydü. Havlucu, her şey vardl. Her şey elimizin altındaydl. Market, eczane, sağlık ocă̆ı hepsi bizim oradaydı." [G6: (E, 29), emlakçı, doğma büyüme mahallede yaşayan yerel sakin]

“Cadde bölümü canllydl, fabrika ve perde mağazalarl vardl. Türkiye’nin her yerine cevap veren, yeten mağazalar vardı. Ana cadde full bir çarşıydı. Hep mă̆azaydı. Bazı binaların tamamı perdeciydi. Perdeciler Çarşısı diye geçerdi burası. Ara sokaklarda da bakkal, küçük esnaflar vardı." [G9: (E, 50), perdeci, 25 yıldır mahallede yaşayan yerel sakin]

“Bakkal vardı çokta iyiydi. Veresiye usulü çalışırdl, güven vardı.” [G20: (K, 62), ev hanımı, Osmaniyeli, 25 yildır mahallede yaşayan yerel sakin]

Mahalleye hizmet eden bakkallar ve esnaflar aynı mahallede yaşamlarını sürdürüp, bulunduğu çevreyi iyi bilip mahalle kimliğinin önemli bir öğesi olmaktadır (Duman, 2014).

Sokakta ekonomik bakışa yönelik dün bugün özelindeki değerlendirmeler, insanların yaşadıkları sokakta bulunan her türlü ticari fonksiyon; yakınlık, tanınırlık, çeşitlilik, güvenilirlik, samimiyet gibi kavramları kapsadığı için küçük esnafların insanlar tarafından benimsendiği ve hayatı kolaylaştırdığı ve küçük esnafların her daim olmaları gerektiği şeklindedir.

\section{Ekonomik bakıșa yönelik yarın özelindeki değerlendirmeler aşağıdaki gibidir.}

Sokakta küçük esnaflar kalmalı mı? Sokağı ekonomik olarak canlı tutmak için neler yapılabilir? Sorularının değerlendirmesine göre çoğu kişinin sokaklarda küçük esnafların kalmasını istedikleri ancak bu oluşan yeni yapılaşmayla birlikte kalabileceği umudu içerisinde olmadıkları belirlenmiştir. Ayrıca küçük esnafların insanların birbiriyle kaynaşmasını sağlamakta adeta bir köprü görevi üstlendiği de vurgulanmıştır. Görüşme 
yapılan kişiler, sokağı ekonomik olarak canlı tutmak için eski çarşının devamının sağlanması ve eski esnafın desteklenmesi gerektiğini belirtmişlerdir.

"Kalmalı, çünkü insanların kaynaşması için kilit nokta oluyor. Küçük esnaflar olunca insanların birbiri ile iletişimi artıyor, dayanışma artar.” [G3: (E, 57), yazar ve mefruşat-perde işiyle meşgul dükkân sahibi, Urfalı, 1977 'ten beri mahallede yaşayan yerel sakin]

"Kalmalı kesinlikle. ... Bakkalda selam verirsin. Eşin, dostun anahtar, başka bir şey emanet bırakabilir bakkala." [G5: (E, 26), perdeci, doğma büyüme mahallede yaşayan yerel sakin]

“Kalmall. Kalması nedensiz olmall, nedene gerek yok bence. Süper marketteki kasiyerdeki kişiyle muhabbet edemiyorsun, günlük olaylarl, mahallede ne olup bitiyor konuşamazsın. Bakkal da tam tersi bunun mahallede ne olup bittiğini öğrenirsin, iş çıkışı gelmişsin bir güler yüz sohbet bile insanın stresini alır.” [G6: (E, 29), emlakçı, doğma büyüme mahallede yaşayan yerel sakin]

“Pratik çözümler sunuyorlar. Bir de komşular arası dayanışmanın anahtarı gibiler.” [G21: (K, 54), ev hanımı, Bakırköy’den gelmiş, 20 yıldır mahallede yaşayan yerel sakin]

"Bulunulan alan üzerinde ihtiyaçların arz ve taleplerin tespitleri araştırılıp en önemliler neyse çalışmalar yapılarak istenilen en uygun hale getirilmesi gerekir. Benim dükkânım halen yapılmakta olan Loca Mahal'de olacak. Şimdi geçici olarak burası bize verildi. Sahil park'ta ticari hayat devam ediyor. Kentsel dönüşümün zararı çarşının bütününe bakıldığ zaman Perdeciler Çarşısının tarihinin yok olduğu ve bu yeni yapılanma ile bu kültürün kaybolduğunu görüyoruz. Ekonomik olarak canlı tutmak için proje sahiplerinin, eski çarşııın ve mefruşat yerlerinin tarihinin devam etmesi için reklam ve tanıtımının en iyi şekilde yapılması gerekir.” [G1: (E, 53), mefruşat-perde işiyle meşgul dükkân sahibi, doğma büyüme mahallede yaşayan yerel sakin]

“Oradaki küçük esnafların desteklenmesi gerekir.” [G13: (E, 47), esnaf, 40 yıldır mahallede yaşayan yerel sakin]

Sokakta, ekonomik bakışa yönelik yarın özelindeki değerlendirmeler, sokağın canlılığını ekonomik olarak sağlayan unsurların en önemlisinin küçük esnaflar olduğunu, ticari fonksiyonların fazlalığının, erişilebilir mesafede oluşunun ve çeşitliliğinin bu canlılığı artırmada önemli kilit noktalar olduğunu göstermektedir.

\subsection{Tartışma}

Bu bölümde kentsel dönüşümde sosyal etki değerlendirmesine yönelik yapılan alan çalışması mahalle ve sokak ölçekleri için yaşayanlar üzerindeki etkilerinin aktarıldığı bulgular bölümünden elde edilen sonuçlar, olumluolumsuz özelliklerin karşılaştırıldığı soru kartı yardımı (Tablo 1 ve 2) ile tartışılmıştır. Bu sonuçlar kentsel dönüşümde sosyal etki değerlendirmesine yönelik genel bir çerçevenin oluşturulmasını sağlayabilecektir.

Mahalle kartlarının değerlendirmesi (Tablo 1) mekânsal bakış perspektifinde; dünde aidiyet hissinin, güvenliğin, yardımlaşmanın varlığı, sosyal olanakların yetersizliği ön plandayken bugün için yabancılaşmanın olmasına yönelik olumsuzlukların oluştuğunu, yarın için de eskiye özlemin vurgulandığı geleneksel yapılaşmaya uygun beklentilerin olduğunu göstermiştir. Yaşamsal bakış perspektifinde; dün mahalle kültürünün, ilişkilerin ve bağlılığın varlığı, bugün bu ilişkilerin yok olmaya yüz tuttuğu, yarın için de komşuluk ilişkileri ve güvenlik duygusuna yönelik taleplerin ön plana çıktığını göstermiştir. Ekonomik bakış perspektifinde; dün gelir dağılımının eşit olduğu, bugün alanda gelir farklılaşmalarının oluştuğu, yerel halkın alanı terk etme sürecine girdiği ve ekonomik çöküşlerin olduğu, yarın için de geleneksel ticaretin yaşamasının istendiği, yerel iş olanaklarının artırılmasına yönelik beklentiler tespit edilmiştir.

Tablo 1. Mahalle kartlarının değerlendirmesi

\begin{tabular}{|c|c|c|c|}
\hline Mahalle & Dün & Bugün & Yarın \\
\hline \multirow{5}{*}{ 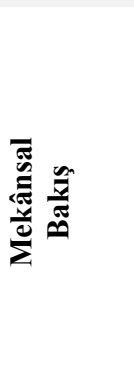 } & $\begin{array}{l}\text {-Aidiyet hissinin yoğun } \\
\text { olarak yaşanması }\end{array}$ & $\begin{array}{l}\text {-Mahallede yabancı kişilerin varlık } \\
\text { göstermesi }\end{array}$ & $\begin{array}{l}\text {-Mahallelinin eskiye özlem } \\
\text { duyması }\end{array}$ \\
\hline & $\begin{array}{l}\text {-Hemşerilik ve komşuluk } \\
\text { ilişkilerinin güçlü olması }\end{array}$ & $\begin{array}{l}\text {-Çoğu kişininin mahalleden ayrılmış } \\
\text { olması }\end{array}$ & $\begin{array}{l}\text {-Eski komşuluk ilişkilerinin } \\
\text { devamının istenmesi }\end{array}$ \\
\hline & -Geleneklerin varlığ & & \multirow{3}{*}{$\begin{array}{l}\text {-Yeşil alanların artırılmasının } \\
\text { istenmesi }\end{array}$} \\
\hline & $\begin{array}{l}\text {-Yardımlaşmanın yoğun } \\
\text { yaşanması }\end{array}$ & & \\
\hline & $\begin{array}{l}\text {-Sosyal aktivite ve yeşil } \\
\text { alanların az olması }\end{array}$ & & \\
\hline
\end{tabular}


oynamalarına yönelik düzenlemelerin yapılması yönünde talepleri olduğu belirlenmiştir. Ekonomik bakış perspektifinde; dün için geleneksel ticaretin varlığı ve canlılığı vurgulanırken, bugün bu canlılığın olmadığ1 ve küçük esnafların yol olmaya başladıkları söylenmiş, yarın için de eski esnafların desteklenmesi, yerel iş olanaklarının artırılması şeklinde beklentileri olduğu tespit edilmiştir.

\section{Sonuç ve Öneriler}

Önceleri ekonomik bir canlandırma aracı olarak görülen kentsel dönüşüm, günümüzde çevresel ve sosyal yönlerinin öne çıkması ile bütüncül bir yaklaşım olarak ele alınmaya başlanmıştır (Roberts,2000). Sürdürülebilirlik dışarıdan müdahalelerle mümkün olamamakta, yerel analiz ve örgütlenme durumu ile dengeli bir yaklaşım ortaya koymayı gerektirmektedir. Bu da sosyal etki değerlendirmesinin önemine işaret etmektedir.

Etkileyen ve etkilenen arasındaki etkileşim sürecinin sosyal ve mekânsal değişime duyarlı hale getirilmesi amacıyla oluşturulan SED raporları, karar alıcıları yönlendirmeyi amaçlamaktadır (Göksu ve ark. 2015).

Türkiye'de kentsel dönüşüm projeleri; planlamadan kopuk, ekonomik kazancı ön plana alan, parçacı fiziksel düzenlemelerle kent parçalarını daha yüksek yapılarla yenileme anlayışıyla ele alınmaktadır. Ancak bu yaklaşım, sorunları çözmek yerine daha büyük sorunlara yol açmaktadır. Kentsel dönüşümün sosyal etkilerine yeteri kadar önemin verilmemesi alanda yabancılaşma, yalnızlık, kültürel değer ve kimlik kaybı, sosyal ayrımlaşma, güvensizlik, ekonomik dengesizlik gibi sorunlar oluşmaktadır. Başarılı bir kentsel dönüşüm için yaşayanların mahalle ve sokak kültürünü, dokusunu, mahallelinin talep ve beklentilerini, alanda kullandıkları bakkal, cami, kahvehane, pazar alanı ve çarşıyı merkeze alan bir dönüşüm projesi hazırlanmalıdır. Bu durum, kentsel dönüşümde SED'in uygulanmasının zorunluluğunu ve sürdürülebilir projelerin bütüncül ele alınması gerekliliğini vurgulamaya neden olmuştur. SED'in mekânsal, yaşamsal ve ekonomik bakışla dünün izlerini, bugünün mahallesini ve yarının projesini değerlendirme imkânı sunması benimsenmesindeki en önemli nedendir.

Kentsel dönüşüm sürecinde projeden etkilenen insanların olumsuz etkilenmemesi, yaşamsal, mekânsal ve ekonomik bakışlarla dün bugün ve yarına yönelik sorunların, etkilerin ve beklentilerin değerlendirilebilmesi için sosyal etki değerlendirme (SED) raporları hazırlanmalıdır. SED raporları ile dönüşümden etkilenen insanlar kaybettikleri ve kazandıkları konusunda bilinçlenmektedir. Bu raporlar, katılımeı süreçlerin uygulanmasını, uzlaşma mekanizmalarının kurulmasını, sorunların çözümüne yönelik önerilerin geliştirilmesini sağlayabilecektir. Böylelikle kentsel dönüşüm sürecinde güven sağlanabilir ve uygulamaların başarısı artabilir. Sosyal etki değerlendirmesi ile kentsel dokudan, mahalle-sokak kültürü kaybına mekânsal problemlerin oluşumunu önleyen, yaşamsal gereksinimleri karşılayabilen, ekonomik yetersizliklere yönelik tavır geliştirebilen mahalle ve sokak olgusu ile insan yaşamında büyük etkiler bırakan kentsel dönüşüm süreçlerinin başarılı olabileceği söylenebilir.

Sümer Mahallesi kentsel dönüşüm projesine yönelik sosyal etki değerlendirmesi çalışması, projeden etkilenen kişilerin katılımcı bir yöntemle, mevcut sokak kullanımını ve mahallenin karakterini anlamayı, mevcut yaşam alışkanlarındaki olası değişikleri ve gelecek yaşam ile ilgili beklentilerini öğrenmeyi sağlamıştır. Projenin sosyal etki değerlendirmesi genel anlamda geçmişin daha iyi yaşam koşulları sağlanarak geleceğe aktarılması gerektiği şeklinde özetlenmelidir.

Kentsel dönüşüm; yörede yasayan nüfusu ile nüfus sosyo-ekonomik ve kültürel özellikleri ile yapılan işin ekonomik çerçevesi ile kapsamlı bir uygulamadır. Katılımın sağlanması, sosyal etkilerin değerlendirilmesi yapılan projelerin kullanıcı tarafından benimsenmesini sağlamaktadır. Alanda yaşayanların beklentilerinin göz önünde bulundurulması ile sürece aktif olarak katılmaları sağlanabilecektir. Proje daha tasarım aşamasındayken hak sahipleri ile bölgede konut alıcılarının profilleri çizilmeli ve iki kesim arasında toplumsal çatışmayı olabildiğince önleyen bir proje tasarlanmalıdır.

\section{Teşekkür}

Bu makale Tuba DEMİREL’in Konya Teknik Üniversitesi Lisansüstü Eğitim Enstitüsü Şehir ve Bölge Planlama Anabilim Dalı'nda Dr. Öğr. Üyesi Neslihan Serdaroğlu Sağ’ın danışmanlığında yürütülmekte olan "Kentsel Dönüşümde Sosyal Etki Değerlendirmesi: Sümer Mahallesi Kentsel Dönüşüm Projesi” isimli yüksek lisans tezi kapsamında hazırlanmıştır. 


\section{Kaynaklar}

1. Akkar Z M (2006). Kentsel dönüşüm üzerine Batı'daki kavramlar, tanımlar, süreçler ve Türkiye. Planlama Dergisi, 2, S. 36, TMMOB ŞPO Yayını, Ankara, 29-38.

2. Alver K (2010). Mahalle: mekân ve hayatın esrarlı birlikteliği. İdealkent, 2, 121-134.

3. Ataöv A, Osmay S, (2007). Türkiye'de kentsel dönüşüme yöntemsel bir yaklaşım. Metu-JFA 2007/2, 24: 2, 57-82.

4. Baday ÖN (2011). Modern kent mekânlarında mahallenin konumu. Yüksek Lisans Tezi, Selçuk Üniversitesi, Sosyal Bilimler Enstitüsü, Sosyoloji Anabilim Dalı, Konya.

5. Barton $\mathbf{H}$ (2000). Conflicting perceptions of neighbourhood in sustainable communities: the potential for eco-neighbourhoods. Barton, H. (Ed.). Conflicting perceptions of neighbourhood in sustainable communities: the potential for eco-neighbourhoods. London: Earthscan.

6. Bektaş Y (2014). Bir kentleşme stratejisi olarak yasanın kentsel mekânı dönüştürmedeki etkisi: Ankara örneği. Planlama 2014, 24:3,157-172. doi: 10.5505/planlama.2014.83803

7. Burdge R, Taylor N (2012). When and Where is Social Impact Assessment Required?

8. Carmona M, Heath T, Oc T, Tiesdell S (2003). The dimensions of urban design. In: Public places urban spaces Oxford: Architectural Press, sayfa 61-193

9. Chan E, Lee GK (2008). Critical factors for 1mproving social sustainability of urban renewal projects. Social Indicators Research, 85:2, 243-256.

10. Demirel D (2018). Kentsel dönüşüm. Tezsiz Yüksek Lisans Dönem Projesi. Siyaset Bilimi ve Kamu Yönetimi Ana Bilim Dalı, Pamukkale Üniversitesi, Denizli. Erișim adresi: http://acikerisim.pau.edu.tr:8080/xmlui/handle/11499/2209.

11. Dempsey N, Bramley G, Power S, Brown C (2011). The social dimension of sustainable development: defining urban social sustainability. Sustainable Development, 19 (5), 289-300.

12. Dinçel ZA (2016). Kentsel dönüşümün çevresel ve sosyal etkileri: Küçükçekmece - Ayazma bölgesi kentsel dönüşüm projesinin incelenmesi. Bitirme projesi, Kadir Has Üniversitesi, İstanbul. Erişim adresi: https://www.academia.edu/29721002/

13. Duman T (2014). Kenar Mahallede Gündelik Hayat. Doktora Tezi, Selçuk Üniversitesi, Sosyal Bilimler Enstitüsü, Sosyoloji Anabilim Dalı, Konya.

14. Dur M (2015). Kentsel Dönüșümün Sosyo-Sültürel Dinamikleri: Konya Örneği. Yüksek Lisans Tezi, Selçuk Üniversitesi, Sosyal Bilimler Enstitüsü, Sosyoloji Anabilim Dalı, Konya.

15. Ertaş M (2011). Kentsel dönüşüm çalışmalarında sosyal boyutun incelenmesi, Ankara ve Londra örnekleri. Selçuk - Teknik Dergisi, 10:1, 1-18.

16. Gittell RJ (1992). Renewing cities. New Jersey: Princeton University Press.

17. Gökgür, P. 2008. Kentsel Mekânda Kamusal Alanın Yeri, Bağlam Yayıncılık İstanbul (Türkçe).

18. Göksu AF, Akalp S, Özkan M, Candan C, Mutlu E, Akkaya B, Ulubaş A, Zaim E (2015). İstanbul: Kentsel Vizyon Platformu, Erişim adresi: https://kentselstrateji.com/proje/sosyal-etki-degerlendirmerehberi-sed/

19. Gürtuna O (2016). Giderek artan bir ihtiyaç: Sosyal Etki Değerlendirme çalışmaları. Madencilik Türkiye, 56, 64-68.

20. Hamiduddin I (2015). Social sustainability, residential design and demographic balance: neighbourhood planning strategies in Freiburg. Town Planning Review, 86:1, 29-52. doi: 10.3828/tpr.2015.3.

21. International Association for Impact Assessment (IAIA) (2009). Social Impact Assessment. Erişim adresi: https://www.iaia.org/wiki-details.php?ID=23

22. İMSAD (İnşaat Malzemesi Sanayicileri Derneği) (2014). Kentsel dönüşüm ve finansmanı. Erişim adresi: https://www.imsad.org/Uploads/Files/kdf_rapor.pdf

23. Jacobs J (1961). The Death and Life of Great American Cities. New York: Vintage Books.

24. Karakitapoğlu EB, Kaya E, Özenirler G (2013). Sosyal Etki Değerlendirme ve Çevre İletişimi, Uluslararası ÇED Kongresi Bildirim Kitabı. S: 151-159. Ankara: Çevre ve Şehircilik Bakanlığı, Çevresel Etki Değerlendirmesi, İzin ve Denetim Genel Müdürlüğü.

25. Kearns A, Forrest R (2000). Social cohesion and multilevel governance. Urban Studies, 37, 995-1017.

26. Keleş, R. 2006. Kentleşme Politikası, İmge Kitabevi Yayınları, Ankara (Türkçe).

27. Kentsel Strateji (2014). Sosyal etkiye duyarlı tasarım süreci, sürdürülebilir şehirler programı kentsel tasarım çalıştayı yöntemi. Erişim tarihi: 09.05.2019, https://www.kentselstrateji.com/wpcontent/uploads/T-02_GaziantepSET.pdf

28. KİPTAŞ (2019). İstanbul Büyükşehir Belediyesi’ne bağlı Konut İmar Plan Sanayi ve Ticaret Anonim Şirketi (KİPTAŞ) dijital arşivi, İstanbul.

29. McCarthy J (2007). Partnership, Collobrative, Planning and Urban Regeneration. Alexander, E.R. (Ed.). Evaluation in planning evolution and prospects, USA: Ashgate Publishing Company. 
30. Öngören G, Çolak İN (2013). Kentsel dönüşüm hukuku kentsel dönüşüm rehberi. 1. bask1. İstanbul: Öngören Hukuk Yayınları.

31. Öngören G, Bayraktaroğlu E, Çamlıbel E (2015). Kentsel Dönüşümün Finansmanı. Ankara: Çevre ve Şehircilik Bakanlı̆̆ için hazırlanmış rapor.

32. Özden PP (2008). Kentsel Yenileme: Yasal Yönetsel Boyut, Planlama ve Uygulama. 2. baskı. İstanbul: İmge Kitabevi.

33. Relph E (1976). Place and Placelessness. London: Pion

34. Roberts P (2000). The Evolution, Definition and Purpose of Urban Regeneration. Peter Roberts, P. \& Sykes, H. (Ed.). Urban Regeneration. Londra: Sage Publications.

35. Rodney B, Clark P (2000). Financing urban regeneration, Real Estate Finance and Investment Research Paper No: 2000.04. London: City University Business School.

36. Saraç M (2014). Kentsel Dönüşüm ve Gelişimi, Sosyal Boyutu, Kentsel Dönüşümden Doğan Hukuki Sorunlar. Yüksek Lisans Tezi, Çankaya Üniversitesi, Sosyal Bilimler Enstitüsü, Özel Hukuk Anabilim Dalı, Ankara.

37. Serdaroğlu Sağ N (2011). Dönüşüme Bağlı Kentsel Gelişmenin Yönetilmesinde Bir Araç Olarak Akıllı Büyüme; Konya Kenti Örneği. Doktora Tezi, Selçuk Üniversitesi, Fen Bilimleri Enstitüsü, Şehir ve Bölge Planlama Anabilim Dalı, Konya.

38. Seyidoğulları HS (2016). Yeni yasal düzenlemelerle kentsel dönüşüm. Planlama 2016; 26:1, 51-64. DOİ: 10.5505/planlama.2016.54254

39. Turcu CL (2010). Examining The İmpact of Housing Refurbishment-led Regeneration on Community Sustainability: A Study of Three Housing Market Renewal Areas in England. Phd Thesis. The London School of Economics and Political Sciences, Department of Social Policy of the London School of Economics, London.

40. URL-1: Sosyal etki tasarımı SET Rehberi Yöntem Kartları. Erişim adresi: https://www.kentselstrateji.com/wp-content/uploads/SET-yontemkartlari.pdf , Erişim tarihi: 20.05.2019

41. URL-2: Zeytinburnu ilçesi konum fotoğrafi. Erişim adresi: http://sehirharitasi.ibb.gov.tr/ , Erişim tarihi: 09.05.2019

42. URL-3: Ysehircilik Yeni $\quad$ Bildirgesi. https://www.cnu.org/sites/default/files/charter_in_turkish.pdf,Erişim tarihi: 20.05.2019

43. Usalan H (2017). Kentsel Dönüşümün Çevresel Boyutları. Kent Ekonomisi ve Kent Yönetimi Dersi Sunuş Raporu, Ankara Üniversitesi, Gayrimenkul Geliştirme ve Yönetimi Anabilim Dalı, Ankara. Erişim adresi: https://www.academia.edu/36729547/

44. Vanclay F (2003). International principles for Social Impact Aassessment. Impact Assessment and ProjectAppraisal, 21:1, 5-12.doi: 10.3152/147154603781766491

45. Vanclay F (2012). New Developments in Social Impact Assessment, University of Groningen.

46. Yağcı C (2014). Kentsel Dönüşüm Projelerinde Fiziksel Değişimin Coğrafi Bilgi Sistemi (CBS) Yoluyla Araştırılması. Yüksek Lisans Tezi. Selçuk Üniversitesi, Fen Bilimleri Enstitüsü, Harita Mühendisliği Anabilim Dalı, Konya.

47. Yenice S (2011). Tarihi Kent Merkezlerinde Sürdürülebilir Yenileme İçin Bir Model Önerisi; Konya Örneği. Doktora Tezi. Selçuk Üniversitesi, Fen Bilimleri Enstitüsü, Şehir ve Bölge Planlama Anabilim Dal1, Konya.

48. Yıldız B (2016). Kamusal Mekân ve Erişilebilirlik Kavramları Kapsamında Bursa Tarihi Hanlar Bölgesinin İrdelenmesi. Yüksek Lisans Tezi. Bahçeşehir Üniversitesi, Fen Bilimleri Enstitüsü, Kentsel Sistemler ve Ulaştırma Yönetimi Yüksek Lisans Programı, İstanbul. 